\title{
Horseshoe crab trace fossils from the Upper Cretaceous Two Medicine Formation of Montana, USA, and a brief review of the xiphosurid ichnological record
}

\author{
Masateru Shibata $^{1}$ and David J. Varricchio ${ }^{2 *}$ (1) \\ ${ }^{1}$ Institute of Dinosaur Research, Fukui Prefectural University, Fukui, Japan <shibata.masateru@gmail.com> \\ ${ }^{2}$ Earth Sciences, Montana State University, Bozeman, MT 59717, USA <djv@ montana.edu>
}

\begin{abstract}
A locality in the Upper Cretaceous Two Medicine Formation of Montana preserves abundant and variable horseshoe crab tracks and trails of the ichnotaxon Kouphichnium isp. These specimens span six morphologies differing in track form and trail configuration. These differences likely reflect variations in track-maker locomotion and behavior, substrate consistency, epichnial versus hypichnial preservation, and undertrack versus true tracks. Several tracks preserve the first clear appendage impressions for an extinct horseshoe crab. This discovery adds new information to the fossil horseshoe crab diversity in the Cretaceous Period. Trackway dimensions, such as the external width across the pusher legs or of the prosomal drag mark, provide information on the track-maker size. Most trackways correspond with crabs 9-14 cm wide; the abundance but limited size range of the traces suggests the large assemblage corresponds to a mating aggregation. The trace fossil record of xiphosurids indicates that throughout their history, horseshoe crabs inhabited both marine and nonmarine settings. They were definitively present in freshwater habitats from the lower Carboniferous through at least the Paleogene. Horseshoe crab trace abundance is highest from the upper Carboniferous through the Jurassic and likely reflects two factors: true upper Carboniferous taxonomic diversity and a preponderance of suitable sites for trackway preservation in the Late Triassic and Jurassic. Cretaceous traces are uncommon, and this Two Medicine locality is the first occurrence of horseshoe crab traces in the Late Cretaceous worldwide. Overall, track abundance and diversity would seem to correspond well with the reported horseshoe crab body fossil record.
\end{abstract}

\section{Introduction}

Horseshoe crabs of the Limulidae survive today in areas along the East Coast of North America, western Japan, and restricted regions of East and Southeast Asia (Sekiguchi, 1999). Three genera and four species represent the entire existing diversity of both the family and the entire Xiphosurida. Although the fossil record of the Xiphosurida extends into the Paleozoic, the general bauplan of the order has undergone very little change, and Limulus has been proposed as a stabilomorph (Kin and Błażejowski, 2014; but see Lamsdell, 2016, for a different view). The characteristic horseshoe crab exoskeleton, consisting of three major sections (the prosoma, opisthosoma, and telson), was established by the Carboniferous Period within the Limulidae (Størmer, 1955; Shuster, 2001a). Fossil horseshoe crabs occupied a variety of environments, including lakes, rivers, and marine habitats (e.g., Reeside and Harris, 1952; Schram, 1979; Babcock et al., 2000; Lamsdell et al., 2013; Lamsdell, 2016; Błażejowski et. al., 2017). By contrast, except for one species in Southeast Asia, extant horseshoe crabs are limited to strictly marine settings (Sekiguchi, 1999). Despite differences among extant species, horseshoe crabs generally live in coastal bays with mud flats in

*Corresponding author low tide, climbing beach slopes for mating and spawning (Sekiguchi, 1999; Shuster, 2001a). Lamsdell (2016) has undertaken the most rigorous investigation of horseshoe crab paleoecology, combining the body fossil record with a phylogenetic analysis. He found at least five independent colonizations of nonmarine habitats occurring within the xiphosurids, with two represented by major clades, Belinurina and Austrolimulidae (Lamsdell, 2016). The former occupied in part Carboniferous swamps and the latter largely Permo-Triassic fluvial systems. Limulids spread to freshwater environments twice during the Mesozoic, but these were both low-diversity events (Lamsdell, 2016). After the Early Cretaceous, the limulid body fossil record is restricted to marine deposits (Lamsdell, 2016).

Confusion over horseshoe crab trackways has included their misinterpretation as footprints of pterosaurs (Oppel, 1862; Winkler, 1886), Archaeopteryx (Nopsca, 1923), and amphibians (Willard, 1935). Abel (1935) first recognized horseshoe crab traces in the fossil record, and Caster (1938) used experimental work to reinterpret the amphibian tracks of Willard (1935) as having a limulid origin. The type species for horseshoe crab tracks, Ichnites lithographicus, was originally described by Oppel (1862) as pterosaur tracks. Later, Nopcsa (1923) reassigned this ichnospecies to the ichnogenus Kouphichnium and as representative of Archaeopteryx tracks. Caster (1944) compiled previously described limulid-like tracks (e.g., Willard, 1935) and concluded 
that morphological differences among them reflected variations of horseshoe crab behavior. In addition, Caster (1944) applied the ichnogenus Kouphichnium to Triassic horseshoe crab tracks.

The generally autochthonous nature of trace fossils makes them particularly useful as paleoenvironmental indicators. Because of the primarily marine existence of extant horseshoe crabs, limulid trace fossils were considered to indicate a marine environment (Anderson, 1975). However, several fossil horseshoe crabs have inhabited nonmarine settings (e.g., Riek, 1968; Riek and Gill, 1971; Pickett, 1984; Babcock et al., 2000; Lamsdell, 2016; Błażejowski et al., 2017). In addition, their trace fossils have been described from nonmarine sediments (e.g., Russell, 1940; Romano and Whyte, 2003; Hasiotis, 2004; Lucas et al., 2006; Fillmore et al., 2010; Shu et al., 2018). Osgood (1987) originally considered Kouphichnium isp. as part of the Scoyenia ichnofacies, representative of general nonmarine environments, but more recently, Buatois and Mángano (2002) considered a Carboniferous occurrence as part of the Mermia ichnofacies reflective of moderately persistent floodplain water bodies and water-saturated substrates.

The Campanian Two Medicine Formation crops out in northwestern Montana and has yielded an abundance of dinosaur bones (Rogers, 1997). Although dinosaurs from the Two Medicine Formation have been well studied, there has yet to be a formation-wide examination of trace fossils. Horseshoe crab and other trace fossils were discovered in the lower part of Two Medicine Formation near Choteau, Montana. The abundant specimens from the study area represent one of the larger documented assemblages of horseshoe crab traces and preserve varied morphology and configurations and include not only 'foot' (chelae), but also leg impressions. Thus, this assemblage provides the opportunity to assess the morphologic variability within an ichnotaxon and to assess the 'population structure' as represented by the size distribution of the numerous trackways.

In addition, this represents the first record of horseshoe crab trace fossils from this formation and only the third occurrence of horseshoe crabs in the Cretaceous of North America. The two earlier records consist of body fossils from marine deposits. By contrast, the Two Medicine Formation represents primarily an inland depositional setting (Rogers, 1997), and the existence of horseshoe crabs in this formation may be environmentally significant.

The trace and body fossil records of horseshoe crabs demonstrate their wide geographical distribution, nearly worldwide in the past, and longevity, ranging from the Paleozoic to Recent. Although Sekiguchi (1999), Shuster (2001a), and Shuster and Anderson (2003) briefly mention horseshoe crab paleobiogeography in terms of their body fossil records, with Lamsdell (2016) taking a much more exhaustive review, a recent review of the trace fossil record is lacking. But see Moreau et al. (2014) for an extensive consideration of trace and body size variation through time. Our study has two objectives: (1) to describe horseshoe crab track morphology and trail configuration from the Two Medicine Formation and (2) to explore potential horseshoe crab habitat preferences through a review of trace fossil occurrences.

\section{General description}

The body of the horseshoe crab consists of three main parts- the prosoma (anterior carapace), opisthosoma (abdominal carapace),

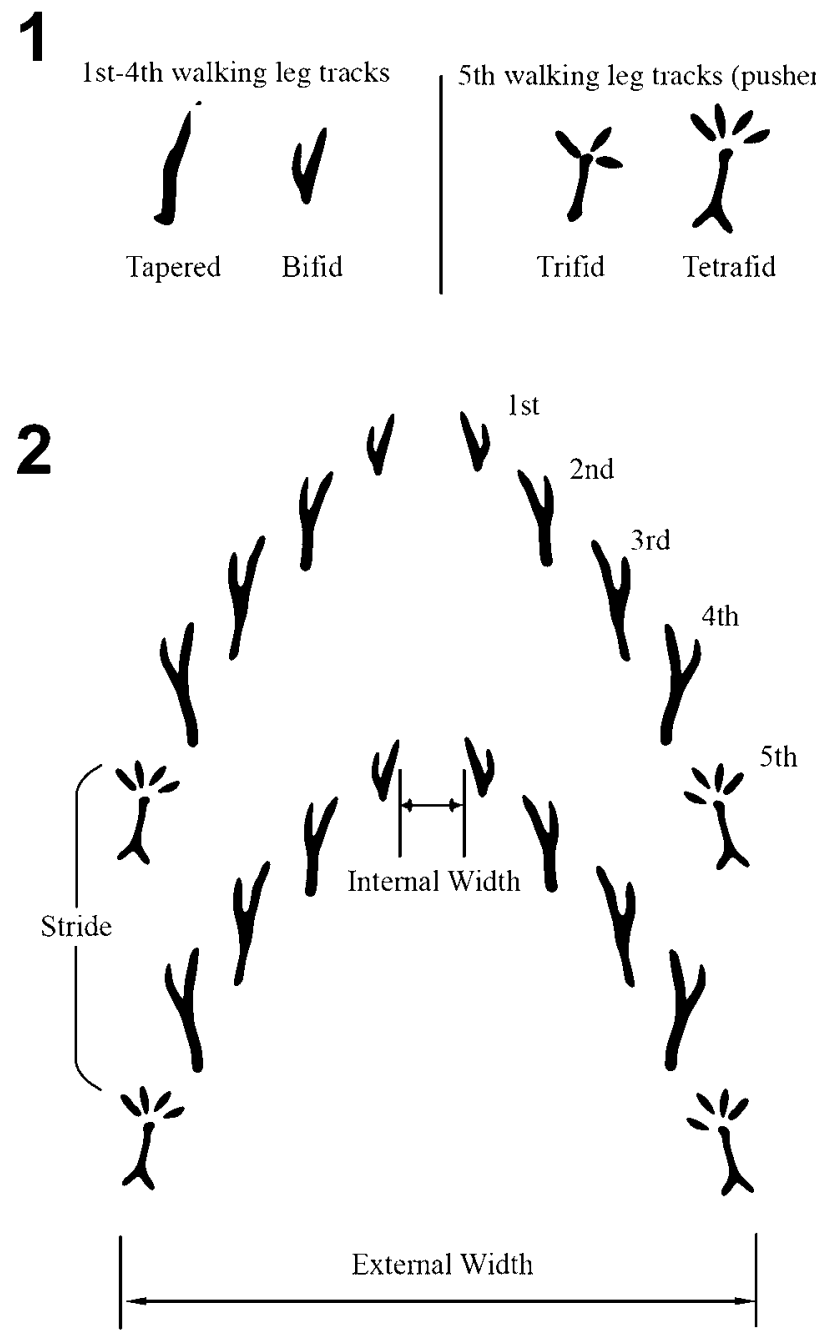

Figure 1. Ideal Kouphichnium isp. tracks. (1) Expressions for each foot representing the first through fourth walking legs and the pusher; (2) two complete cycles of tracks showing location of external width, internal width, and stride measurements.

and telson (tail) —and bears seven pairs of appendages on the ventral side of the prosoma. The most anterior and posterior appendages (pairs 1 and 7) are not employed for walking, but for feeding (Sekiguchi, 1999). Extant horseshoe crabs generally use the second through sixth pairs of appendages for locomotion; thus, these are called the first to fifth walking legs (Sekiguchi, 1999). Each of the first four walking legs bears a bifid foot. The fifth walking leg bears four spine-like digits anteriorly and two posteriorly. This walking leg is called the 'pusher' leg because it operates in a snowshoe-like fashion during locomotion on a substrate. The anterior four walking legs generally make a tapered or bifurcated pattern in the sediment, whereas the last, or pusher, leg may generate a variety of tracks depending on the substrate (Caster, 1938, 1944; Goldring and Seilacher, 1971; Shuster, 2001b) (Fig. 1). Overall, progression of these 'crabs' can produce a diversity of tracks and trails (Caster, 1938).

Caster $(1938,1944)$ described the production of the trackways from observations of the living American horseshoe crab, Limulus polyphemus (Linnaeus, 1758). According to Caster (1938), L. polyphemus produces a bilateral trail that ideally 


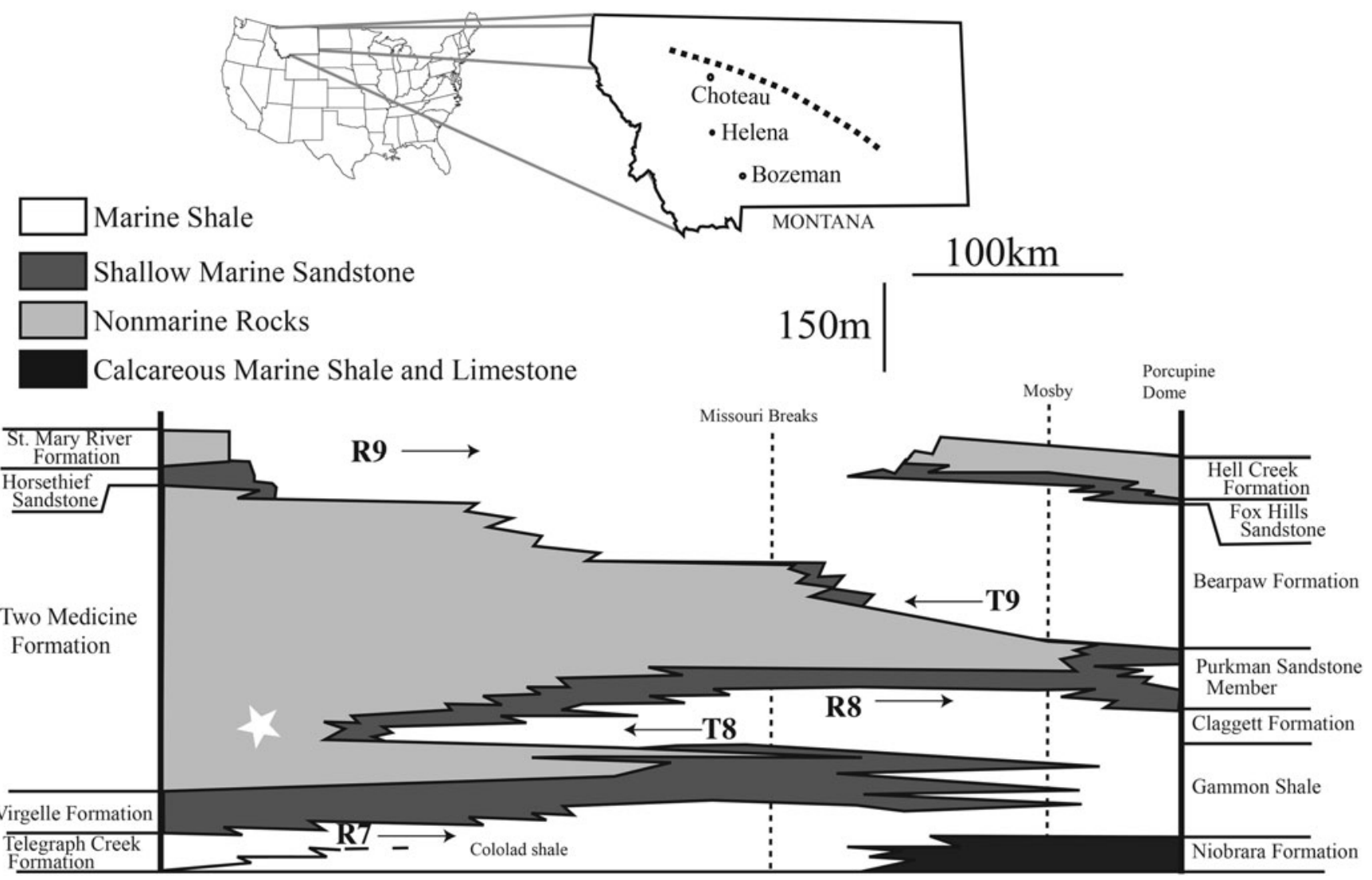

Figure 2. Schematic cross section of Montana Group and brief map of Montana after Rogers (1998). Dashed line on map shows the line of the cross section, and solid star indicates the stratigraphic position of the Kouphichnium isp. site. $\mathrm{R}=$ regressive sequence; $\mathrm{T}=$ transgressive sequence.

consists of five simple tracks and one more-complex track on each side. However, the first pair of tracks represents the first pair of appendages, the chelicera. Since these are used primarily for feeding, they seldom produce tracks (Caster, 1938; Sekiguchi, 1999). More commonly, a complete set includes four simple tracks and one digitate track on each side (Fig. 1). The first four walking legs produce simple bifid or tapered tracks, and the fifth walking leg, or pusher, generates the hindmost 'digitate' track (Caster, 1938). Caster (1938) referred to the pusher track as trifid or tetrafid for convenience as the trace could include three, four, or five anterior radiating blade imprints and even a posterior directed impression. Caster (1938) considered a track series with four simple tracks and a pusher track as one step (Fig. 1). When walking, horseshoe crabs employ their appendages in the following order. First, they place the first four walking legs into the ground to raise the body. Second, the pushers extend against the ground to move the body forward before the first four walking legs are repositioned for landing. The trackway sometimes occurs together with a telson and/or prosomal dragging mark (Caster, 1938).

\section{Geologic setting}

The Upper Cretaceous Two Medicine Formation crops out in northwestern Montana and consists of $530 \mathrm{~m}$ of nonmarine strata, including mudstone, siltstone, and sandstone (Rogers, 1997, 1998). Rocks of the formation largely represent alluvial plains with shallow streams and floodplains with often calcareous soils and shallow ponds and lakes (Rogers, 1997). The Two Medicine Formation overlies the shallow-marine Virgelle Sandstone and is in turn overlain by the shallow-marine Horsethief Sandstone (Fig. 2). Two regressions (R7 and R8) and two transgressions (the Claggett, T8, and the Bearpaw, T9) (Fig. 2; Gill and Cobban, 1973; Rogers, 1998) occurred during deposition of the Two Medicine Formation. Rogers et al. (1993) dated the Two Medicine Formation at the onset of the lower transgression (T8) to be $79.6 \pm 0.01 \mathrm{Ma}$ by means of ${ }^{40} \mathrm{Ar} /{ }^{39} \mathrm{Ar}$.

The horseshoe crab trace fossils occur in the lower part of the Two Medicine Formation (Fig. 2) in exposures along the Sun River near Choteau in Teton County, Montana. The lower contact of the Two Medicine Formation with the Virgelle Sandstone is not exposed in this area. However, on the basis of observable strata, the horseshoe crab locality occurs approximately $90 \mathrm{~m}$ above the Virgelle Sandstone (Fig. 3). The Two Medicine Formation in this region consists mainly of mudstone, siltstone, and very fine sandstone. Fine sandstones and siltstones with green or gray color are dominant. Flaser and herringbone cross-bedding occurs in horizons about $40 \mathrm{~m}$ below those yielding the horseshoe crab traces. A few fragments of vertebrate bones were scattered in one poorly sorted siltstone horizon (Fig. 3).

Lithologies immediately preceding the trace locality include first a sequence of varied mudstones bearing root traces, then a sequence of light-colored platy beds. The horseshoe crab trace fossils occur in consecutive sandy siltstone to very fine sandstone horizons representing a total thickness of a few centimeters within a sequence of platy, thickly laminated to thinly bedded 


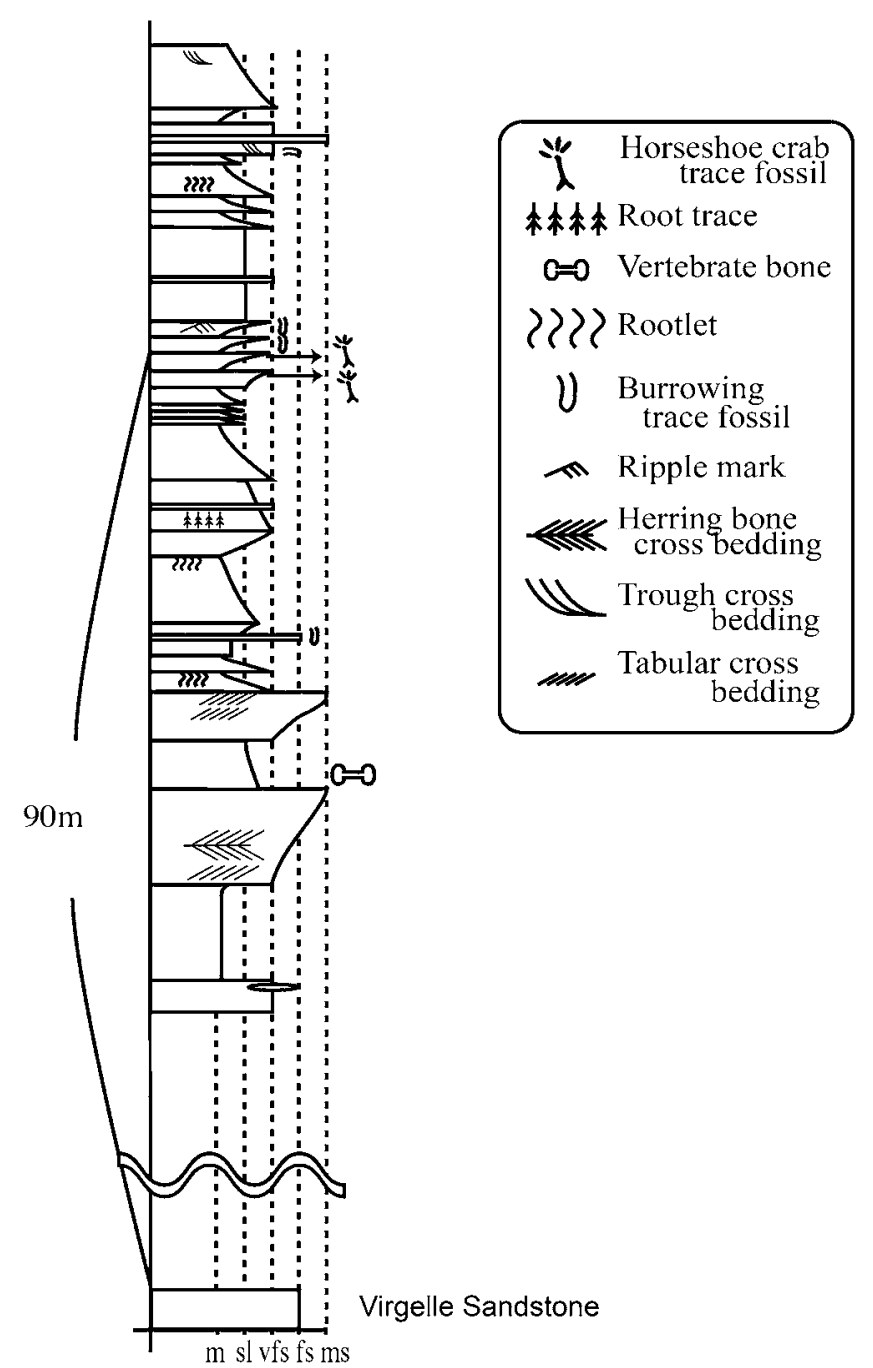

Figure 3. Geological section of the horseshoe crab trace fossil sites along the Sun River near Choteau, Montana. Traces studies herein come from the lower of the two horizons. Boundary with the Virgelle Sandstone is unclear as section is covered.

units with small-scale ripples and fine subrectangular cracks. The latter occur in association with very thin fine-grained lamina; their shallow and more orthogonal pattern suggests these do not represent mud cracks. Instead, the patterning is reminiscent of 'elephant-skin structures' considered to form under microbial mats (Seilacher, 2007). Small-scale desiccation cracks do occur on portions of thin claystone horizons. A second occurrence of trackways occurs approximately $1 \mathrm{~m}$ above this first track horizon. The lower of the two track-bearing beds contains more horseshoe crab traces than the upper one and is the focus of this study. Horizontal burrows and asymmetric ripples were observed in similar coarsening-upward layers above the two principal horizons (Fig. 3).

\section{Materials and methods}

Measurements and descriptions of horseshoe crab traces follow Trewin (1994). External width, internal width, and stride of each walking step were measured with calipers (Fig. 1). External width represents the distance between the outermost imprints of contralateral pusher tracks. However, when pusher tracks were absent, the width of the prosomal drag mark, if present, was measured as an estimate of trackmaker size. Internal width is the separation between the innermost tracks (i.e., those of the first walking legs). Internal variation in trackways made stride difficult to measure. In general, stride was measured as the distance between consecutive pusher tracks. If no pusher tracks were available, then the distance between consecutive tracks of the first walking leg was substituted, provided each step cycle retained the same track configuration.

Repositories and institutional abbreviations.-All specimens are curated at the Museum of the Rockies (MOR), Montana State University, Bozeman, Montana, USA. USNM = United States National Museum.

\section{Systematic ichnology}

Weathering had exposed and fragmented the specimens described here into large slabs in the field. Despite this, they appeared to have suffered minimal damage and remain in good condition. Several additional trace fossil taxa occur in association with the horseshoe crab traces.

\section{Ichnogenus Kouphichnium Nopcsa, 1923}

Type species.—Kouphichnium lithographicum (Oppel, 1862) from the Jurassic Solnhofen Formation, Bavaria, Germany.

\section{Kouphichnium isp.}

Figures 4-8

Diagnosis.-Heteropodous tracks of great variability; complete track consisting of two kinds of imprints, (1) two chevron-like series each of four oval or round holes or bifid V-shaped impressions or scratches, forwardly directed (made by anterior four pairs of feet), and (2) one pair of digitate or flabellar, toe-shaped or otherwise variable imprints made by bird-foot-like 'pushers' of fifth walking pair of feet, with their four or five leaflike movable blades; track with or without median drag mark (Häntzschel, 1975).

Description.-Thirty-nine slabs with trace fossils were collected in 1998 and 2000. In total, 36 trails are recognizable across the slabs, representing 33 separate trackways as three trails are observable on both sides of the thin slabs. Twenty-six trails represent hypichnia (i.e., casts on the bottom side of the layer) whereas 10 are epichnia on the upper surface (Martinsson, 1970). Both hypichnia and epichnia are employed to express whether a track is a convex or concave state on a slab, but not whether it is an undertrack or not.

Kouphichnium isp. from the Two Medicine Formation exhibit variable types of morphology and configuration concerning both individual tracks and trails (Table 1). For example, although no five-bladed pusher tracks occur, both the trifid and tetrafid condition are preserved on several slabs. In addition, the Two Medicine specimens can be divided into six types on the basis of their configurations of tracks and independent of their hypichnial and epichnial occurrence. These are 

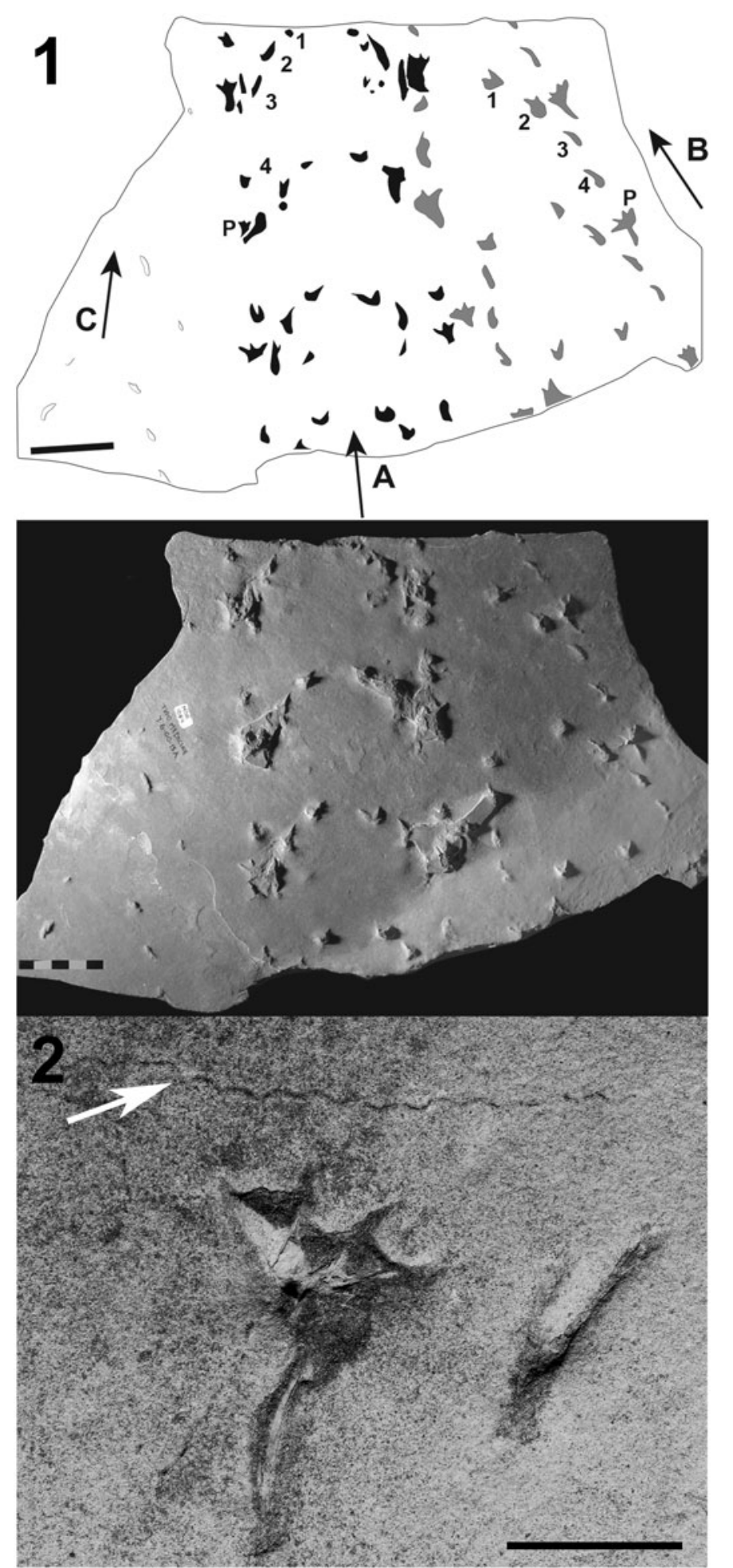

Figure 4. (1) Hypichnial Kouphichnium isp. trackways (MOR 1084-1) from the Two Medicine Formation. Trackway A (black) represents Type I, whereas trackways B (gray) and C (white) are Types II and VI, respectively. Black arrows show direction of movement. $1-4=$ simple tracks of first four walking legs; $\mathrm{P}=$ fifth or pusher track. Scale bars $=5 \mathrm{~cm}$. (2) Close-up of epichnial tetrafid pusher and bifid walking tracks together with a Cochlichnus isp. trace (white arrow). Movement of horseshoe crab is toward the top Scale bar $=1 \mathrm{~cm}$.

distinguished as Type I to Type VI for convenience, as there is a continuum of morphologies within and in some cases across types (Table 1).
Type I trackways are by far the most common form within the assemblage (20 of 36 specimens) (Table 2). This trackway type preserves a complete set of tracks, including four simple tracks and a pusher track on each side in each set (Fig. 4). Type I trails can occur as either epichnia or hypichnia with the first four simple tracks arranged in a posterior curving arc and showing either pointed or bifid morphologies (Fig. 4). Pusher tracks may be either trifid or tetrafid. Slight variations occur in track configurations. For example, the fourth simple track may occur closer to the pusher track than to the third simple track. But these same tracks are more evenly spaced in other Type I examples (Fig. 4). Telson drag marks are more common with epichnial preservation. The two examples of Type II trackways, MOR 1084-1B and 1084-6A, show a similar track configuration to that of Type I, but exhibit more extensive anatomy of the walking legs, including clear impressions of the distal segments (chela and carpus) (Fig. 5). This hypichnial trackway is asymmetric in that the tracks on the right side are all more deeply impressed.

Type III specimens, such as that found on MOR 1084-14A, represent hypichnial trackways, preserving unclear tracks but a distinct telson drag mark (Fig. 6). An example is found in the distinct and straight telson drag mark that occurs between contralateral pusher tracks, although the shape of these remains unclear. Simple and pusher tracks are recognizable; however, no clear arrangement of simple tracks as seen in Types I and II exists. The deep, sweeping impressions of the tracks together with visible swirls of sediment suggest the original sediments likely contained more water than in examples of Types I and II.

The Type IV trail differs from all other configurations because it lacks any clear indication of tracks. Instead, these trails consist of prosomal drag marks (Fig. 7). The five Type IV specimens include both hypichnial and epichnial examples and those with and without telson drags. Several weak grooves run in parallel with both sets of drag marks. Two epichnial Type IV trails, MOR 1084-5A and 1084-15 (Table 2), correspond with Type I hypichnial trackways on the underside of the slab (Fig. 7).

Type $\mathrm{V}$ trackways consist only of a series of evenly spaced pusher tracks with tetrafid digit shape (Fig. 8; Table 2). No simple tracks or drag marks are observed. Pusher tracks may include posterior digit impressions and be angled slightly toward the midline (Fig. 8). Pushers occur at regular intervals and in phase. Additional isolated pusher tracks occur on some slabs, suggesting that more Type $\mathrm{V}$ trackways could be recognized with more complete preservation of the horizon.

Type VI trackways show weak impressions of simple pointed or bifid tracks, without any pusher tracks (Figs. 4, 5, 7; Table 2). These consist mainly of simple tracks variably corresponding to the first two or the first three walking legs. Three examples of Type VI trackways are recognized with hypichnial preservation. One hypichnial Type VI trackway, MOR 1084-5, corresponds to an epichnial Type I trackway (Fig. 7), indicating deeper penetration of the simple walking legs in comparison to the pusher legs.

Although the Two Medicine specimens exhibit varying morphologies and track arrangements, they all in some ways correspond with the ichnogenus Kouphichnium as defined by Häntzschel (1975, p. W75) (Table 1). Types I and II correspond most closely with the definition in preserving a complete set of both kinds of imprints. Three of the four remaining types preserve portions of the ichnogenus as defined: Type V, pusher 

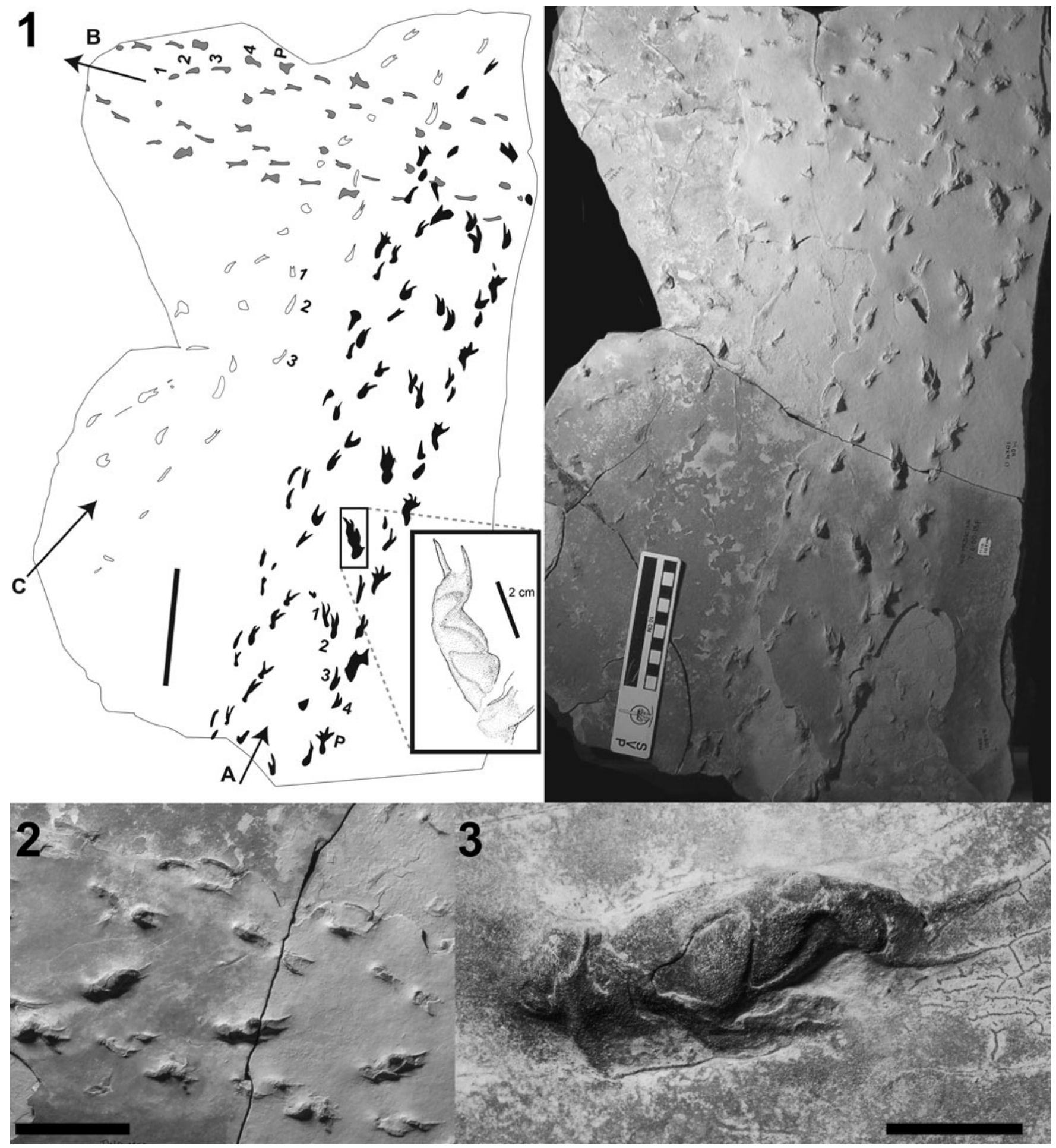

Figure 5. Hypichnial Kouphichnium isp. trackways (MOR 1084-6) from the Two Medicine Formation. (1) Trackway A (black) represents Type II pattern with prominent impressions of walking legs preserving clear impressions of carpi and chelae (see insert). Trackways B (gray) and C (white) are Type I and Type VI patterns, respectively. Arrows show direction of movement. 1-4 = simple tracks of first four walking legs; $\mathrm{P}=$ fifth or pusher track. Scale bar $=10 \mathrm{~cm}$. (2) Close-up of Type II Trackway A. Scale bar $=5 \mathrm{~cm}$. (3) Close-up of single leg impression. Scale bar $=2 \mathrm{~cm}$.

tracks; Type VI, only simple tracks; and Type III, indistinct tracks in association with a telson drag mark. Type IV lacks both kinds of imprints. Nevertheless, the association of the Type IV prosoma trail with a corresponding Type I trackway indicates that this trail should also be recognized as Kouphichnium.
An ichnospecies name is not applied to the Two Medicine specimens due to the existing ichno-taxonomic confusion for horseshoe crab trace fossils. Several ichnospecies have been previously recognized for locomotion: K. arizonae Caster, 1944, K. gracilis and K. variabilis Linck, 1949, and K. pentapodus Erickson, 2005. In general and similar to the Two Medicine 

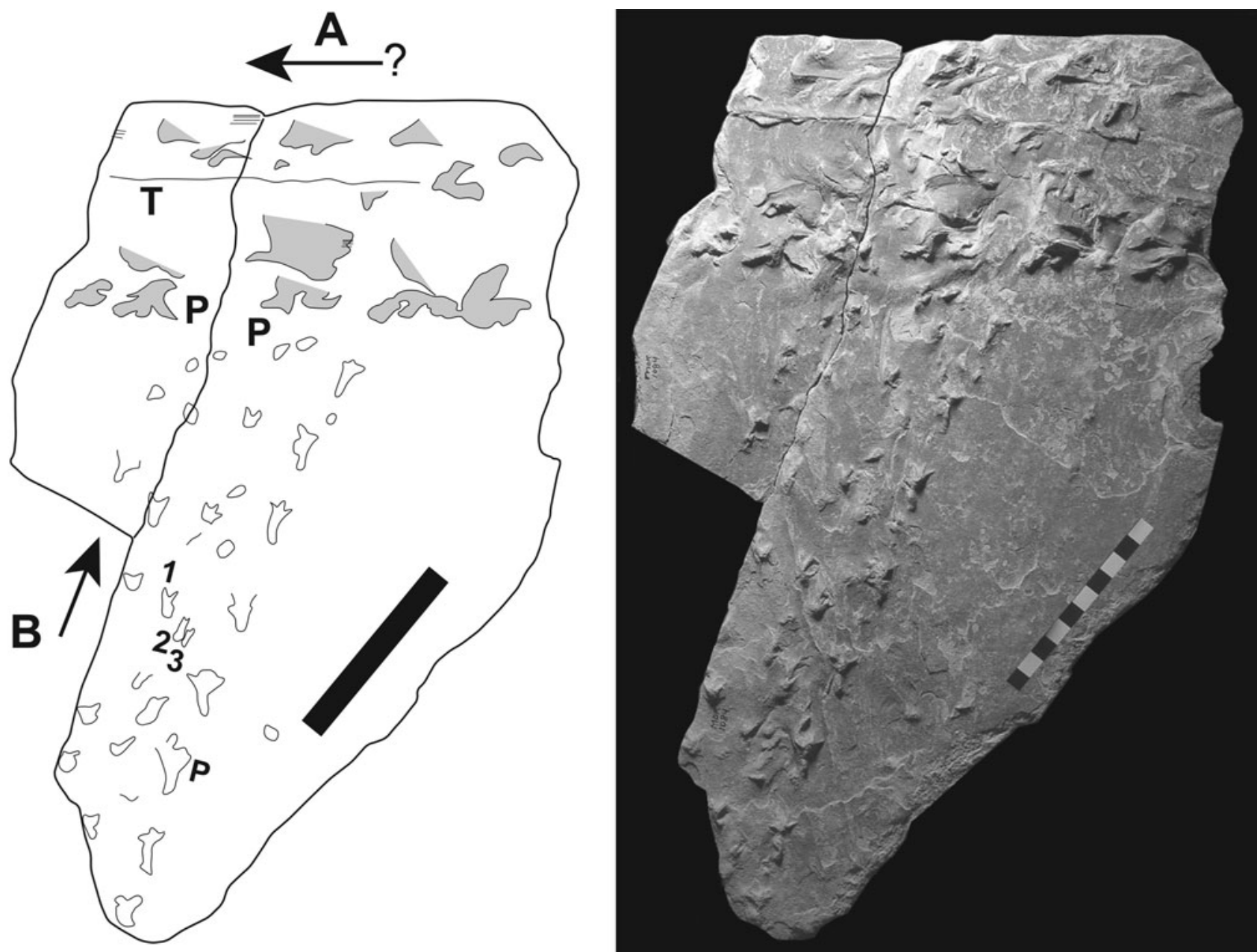

Figure 6. Hypichnial Kouphichnium isp. trackways (MOR 1084-14) from the Two Medicine Formation. Trackway A (gray) shows Type III form with a telson drag mark and unclear pusher tracks. Trackway B (white) is a deformed Type I with simple and pusher tracks. Arrows show direction of movement. 1-3= simple tracks of first four walking legs; $\mathrm{P}=$ fifth or pusher track; $\mathrm{T}=$ telson drag mark. $\mathrm{Scale}$ bars $=10 \mathrm{~cm}$.

assemblage, these appear to reflect a largely uniform anatomy but with variations in substrate and/or behavior. Additional Limulina traces include Limulicubichnus serratus Miller, 1982 for shallow burrowing and Selenichnites hundalensis Romano and Whyte, 1987 for resting. Hasiotis (2004) also recognized resting Kouphichnium traces but did not establish a distinct species.

Materials.-MOR 1084-1, 1084-3-9, 1084-13-18, 1084-23, 1084-29, and 1084-34-37. Kouphichunium isp. are the most abundant traces at this locality and show variable shapes and configurations.

Measurements.-Twenty-one trackways were sufficiently preserved to allow measurement of the external width across contralateral pushers (Table 2). Of these, all but one falls between 9.1 and $13.2 \mathrm{~cm}$, the one exception being only $6.9 \mathrm{~cm}$ wide. The average external width for all is $10.6 \mathrm{~cm}$ (Fig. 9). Internal widths $(\mathrm{n}=17)$ average $2.4 \mathrm{~cm}$ and range from 1.4 to $3.4 \mathrm{~cm}$. Stride length shows much greater variation than the two anatomical widths: $3.9-12.8 \mathrm{~cm}$ with an average of $6.5 \mathrm{~cm}$.

The Two Medicine specimens preserve two epichnial prosomal drag marks associated with corresponding hypichnial undertracks. In both cases, the prosomal drag marks are slightly wider than the corresponding external widths; ratios of drag marks/external widths in these two specimens are 1.16 and 1.01. This is consistent with extant horseshoe crab anatomy, where the prosoma covers most of the walking appendages. Together, the five prosomal trails from the assemblage correspond with the majority of external widths on the basis of pusher positions in ranging from 9.5 to $14.8 \mathrm{~cm}$ with an average of $11.5 \mathrm{~cm}$.

Remarks. - The diverse configurations of Kouphichnium isp. are well described by Goldring and Seilacher (1971), who examined tracks of the upper Carboniferous of Nova Scotia. These tracks were imprinted in laminated siltstone slabs, which could be easily split into thin layers. Thus, Goldring and Seilacher (1971) could demonstrate how the placement of one leg on the substrate produced tracks of differing morphology on underlying layers. In addition, examples included cases with only simple tracks or only pusher tracks preserved (Goldring and Seilacher, 1971, fig. 2A, B). They also demonstrate the better preservation of undertracks. Consequently, the authors concluded that arthropod trace fossils with sharp impressions are likely to be undertracks and that surface tracks are both 


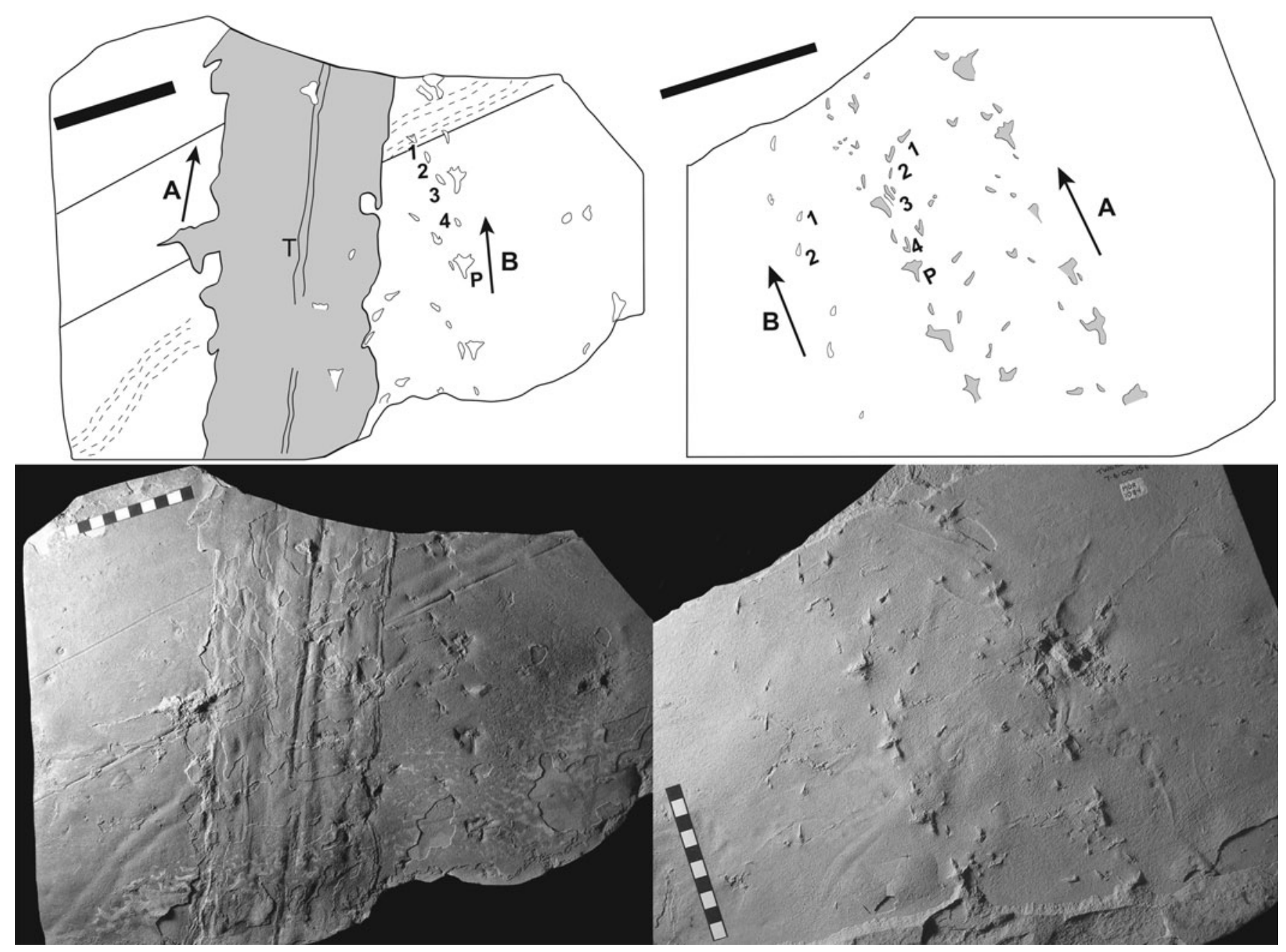

Figure 7. Epichnial and hypichnial views of MOR1084-5 showing two Kouphichnium isp. traces. Trace A consists of an epichnial Type IV (i.e., prosomal drag mark) and a corresponding hypichnial Type I, whereas trace B is represented by a epichnial Type I matching an hypichnial Type VI. Arrows show direction of movement. $1-4=$ simple tracks of first four walking legs; $\mathrm{P}=$ fifth or pusher track; $\mathrm{T}=$ telson drag mark. $\mathrm{Scale}$ bars $=10 \mathrm{~cm}$.

unclear and rare because they tend to suffer from water action. Oishi et al. (1993) in their description of Oligocene horseshoe crab traces from Japan supported this interpretation by demonstrating a relationship between sediment shear strength and the quality of form in traces. Here, the strength of sediment correlates with depth invoking the relationship between void ratio and depth of clay sediment from Ohtsubo and Ibaraki (1991). As a result, Oishi et al. (1993) concluded that tracks are more likely to be preserved within the sediment at depth rather than in more surficial sediments with low shear strength. This is consistent with the observations of Goldring and Seilacher (1971). Both studies suggested that most Kouphichnium isp. from the Two Medicine represent undertracks.

When a horseshoe crab moves, the anterior four sets of walking legs lift the body while the pusher legs push into the sediment to generate forward movement. Consequently, pusher legs are usually forced strongly against the substrate and into the deepest layers (Goldring and Seilacher, 1971). Accordingly, the differences between Types I and V likely reflect varying depths relative to the sediment-water interface, with Type $\mathrm{V}$ being a product of undertrack deficiency (Seilacher, 2007). At more shallow depth within the substrate, all five pairs of legs penetrate to produce a
Type I trackway. But only the pushers penetrate to a deeper horizon producing a Type $\mathrm{V}$ trackway lacking the simple bifid tracks.

Type II has not been reported previously and is interesting in preserving impressions of the legs including carpus and chela. Except for these leg impressions, this configuration is similar to Type I trackways. According to Goldring and Sëilacher (1971), when employed, the first four walking legs scratch the substrate from front to back. This results in a pointed or bifid mark (Goldring and Sëilacher, 1971, fig. 3). However, this motion is unlikely to account for the forward-directed leg impressions of Type II (Fig. 5). If the leg entered the substrate with forward-directed chelae then extended rearward, one would expect any leg impression to suffer distortion. An alternative interpretation for the Type II leg impressions is that the leg entered the substrate moving forward and left an impression when the motion stopped and the leg pulled off the substrate. The asymmetry of the only Type II example suggests the possibility that the animal may have been responding to a strong sideways current or other asymmetric force.

The Type III trail also shows indistinct but relatively deep pusher and possibly simple tracks and a telson drag mark (Fig. 6). The deep impressions $(\sim 2 \mathrm{~cm})$ and their irregular 

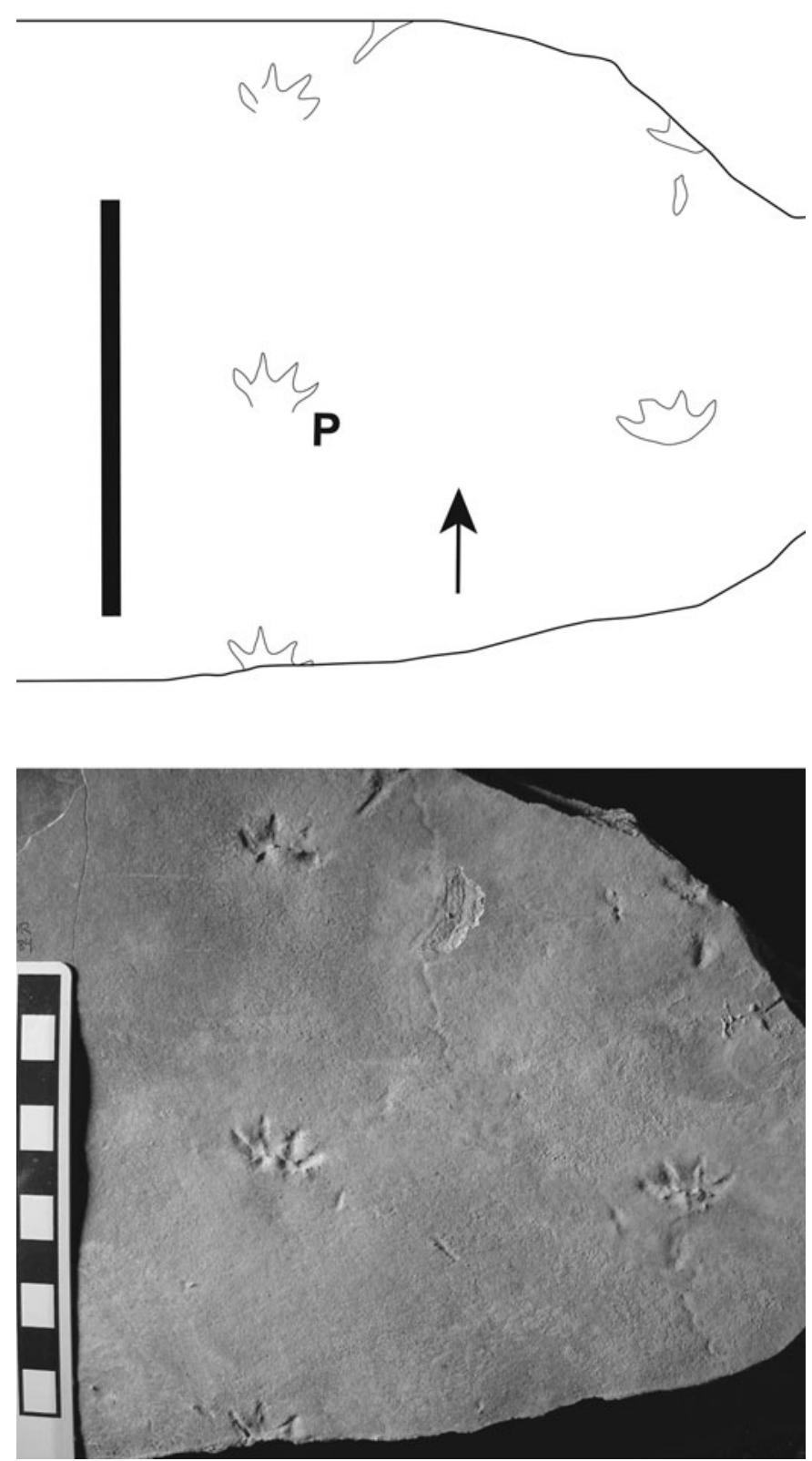

Figure 8. Epichnial Kouphichnium isp. trackway (MOR 1084-8) of Type V from the Two Medicine Formation. Only in-phase pusher tracks are preserved, each with four anterior blade imprints. Arrows show direction of movement. $\mathrm{P}=$ fifth or pusher track. Scale bars $=10 \mathrm{~cm}$.

impressions suggest that the substrate was very soft and waterladen during track making. Type III would represent hypichnial undertracks within thixotropic sediment.

Type IV trails consist primarily of prosomal and telson drag marks. The corresponding occurrence of Type I trackways on the underside of Type IV trails suggests that horseshoe crabs were moving through soft, unconsolidated sediment. As their legs penetrated deep into the substrate, their prosoma and telson would have scraped the upper sediment surface. Epichnial Type IV trails would represent true surface traces, with the corresponding Type I denoting undertracks.

Type VI trackways include only simple tracks from the first four sets of walking legs. Bandel (1967) noted the infrequency of pusher tracks in limulid trackways from the Pennsylvanian Tononoxie Sandstone of Kansas. He attributed the wealth of simple tracks on these specimens to the trackmaker swimming close to the sediment surface as the extant $L$. polyphemus has been observed to do. This explanation may account for some Type VI trackways from the Two Medicine Formation. However, one Type VI specimen represents the undertrack corresponding to a Type I trackway where anterior walking appendages penetrated the substrate more deeply than the pushers (Fig. 7). Consequently, although some Type VI may potentially equate to swimming trackways, they also represent undertracks of walking progression perhaps on moreconsolidated substrates allowing only shallow penetration of the pusher legs.

\section{Ichnogenus Cochlichnus Hitchcock, 1858}

Type species.—Cochlichnus anguineus Hitchcock, 1858 from the Lower Jurassic Turner Falls Sandstone from Turners Falls, Massachusetts, USA, by original designation.

\section{Cochlichnus isp.}

Figure 4.2

Diagnosis.—Regularly meandering trails, resembling sine curve (Häntzschel, 1975).

Description.-Small, wavy-lined impressions that are approximately $1.2 \mathrm{~mm}$ in diameter, from 19 to $40 \mathrm{~mm}$ in total length, and up to $3.6 \mathrm{~mm}$ in amplitude (Fig. 4.2).

Materials.-Four slabs preserving five specimens (MOR 1084-6, 1084-8, 1084-13, and 1084-39).

Remarks.-Buatois et al. (1997) demonstrated two different size classes for Cochlichnus isp. The smaller specimens of Buatois et al. (1997) correspond in both size and proportions to the wavy trace fossils associated with the Two Medicine Kouphichnium isp. Buatois et al. (1997) interpreted this trace type as either a locomotion trace or a combination locomotion and feeding trace by nematodes or ceratopogonids. As for depositional settings, Cochlichnus isp. has been found in a variety of marine and nonmarine environments (Buatois et al., 1997).

\section{Ichnogenus Octopodichnus Gilmore, 1927}

Type species.—Octopodichnus didactylus Gilmore, 1927 (USNM 11501) from the Permian Coconino Sandstone at Hermit Trail, Hermit Basin, Grand Canyon National Park, Arizona, USA, by original designation.

\section{Octopodichnus isp.}

Figure 10

Diagnosis.-Apparently eight-footed with tracks arranged in groups of four, alternating, two anterior impressions didactyl, two posterior unidactyl (Gilmore, 1927). 
Table 1. Types (I-VI) of horseshoe crab traces from the Two Medicine locality.

\begin{tabular}{|c|c|c|c|c|c|}
\hline Type & Relief & Bifid or simple tracks & Pusher tracks & Telson mark & Other distinguishing features \\
\hline I & Hypichnia or epichnia & Present & Present & Absent & Complete set of both simple/bifid and pusher tracks present \\
\hline III & Hypichnia & Unclear to absent & Present but unclear & Present & $\begin{array}{l}\text { Similar to Type I and II, but tracks are deep and unclear; } \\
\text { telson drag is present }\end{array}$ \\
\hline IV & Hypichnia or epichnia & Absent & Absent & $\begin{array}{l}\text { May be } \\
\text { present }\end{array}$ & Prosoma drag mark with or without telson trail \\
\hline $\mathrm{V}$ & Hypichnia or epichnia & Absent & Present & Absent & Only pusher tracks present \\
\hline VI & Hypichnia & Present & Absent & Absent & $\begin{array}{l}\text { Weak impressions of simple or bifid tracks present but } \\
\text { without pushers }\end{array}$ \\
\hline
\end{tabular}

Table 2. Size measurements of the Two Medicine Formation's Koupichnium isp. specimens (MOR 1084). Epichnia marked by *; No. = slab number within MOR $1084 ; \mathrm{n}=$ number of measurements

\begin{tabular}{|c|c|c|c|c|c|}
\hline No. & Trace & Type & External width $(\mathrm{cm})$ & Internal width $(\mathrm{cm})$ & Stride $(\mathrm{cm})$ \\
\hline \multirow[t]{3}{*}{1} & A & I & $12.2(\mathrm{n}=3)$ & $1.9(\mathrm{n}=3)$ & $7.3(\mathrm{n}=2)$ \\
\hline & B & II & $12.4(\mathrm{n}=3)$ & $3.0(n=3)$ & $8.1(n=2)$ \\
\hline & $\mathrm{C}$ & VI & - & $3.4(\mathrm{n}=1)$ & - \\
\hline $3 ?$ & - & I & $10.6(n=3)$ & - & - \\
\hline 4 & - & I & $10.5(n=1)$ & $1.7(n=3)$ & $6.4(n=2)$ \\
\hline \multirow[t]{2}{*}{5} & A & I & $10.4(n=5)$ & $2.7(n=3)$ & $4.2(n=4)$ \\
\hline & B & VI & - & - & $5.6(n=2)$ \\
\hline \multirow[t]{2}{*}{$5^{*}$} & A & IV & 12.1 (prosoma) & - & - \\
\hline & $\mathrm{B}$ & I & $11.5(n=2)$ & $2.5(n=1)$ & $6.9(n=3)$ \\
\hline \multirow[t]{3}{*}{6} & A & II & $10.7(n=8)$ & $2.0(n=9)$ & $6.9(n=6)$ \\
\hline & B & I & $10.3(n=3)$ & $2.2(n=4)$ & $7.1(n=2)$ \\
\hline & $\mathrm{C}$ & VI? & $10.1(n=1)$ & $1.9(n=1)$ & - \\
\hline \multirow[t]{2}{*}{$7 ?$} & A & $\mathrm{V}$ & - & - & $7.1(n=2)$ \\
\hline & $\mathrm{B}$ & $\mathrm{V}$ & - & - & $7.7(n=2)$ \\
\hline $8 *$ & - & V & $11.2(\mathrm{n}=1)$ & - & $6.5(n=2)$ \\
\hline $9 ?$ & - & V & - & - & - \\
\hline \multirow[t]{2}{*}{$13^{*}$} & A & $\mathrm{I}$ & - & - & $6.0(n=2)$ \\
\hline & $\mathrm{B}$ & I & - & - & $7.9(n=1)$ \\
\hline \multirow[t]{2}{*}{14} & A & III & $9.3(n=2)$ & $1.4(\mathrm{n}=1)$ & $4.0(n=6)$ \\
\hline & $\mathrm{B}$ & I & $6.9(\mathrm{n}=5)$ & - & $5.2(n=4)$ \\
\hline $15^{*}$ & - & IV & 9.5 (prosoma) & - & - \\
\hline 15 & - & I & $9.4(\mathrm{n}=8)$ & $1.9(n=3)$ & $3.9(\mathrm{n}=8)$ \\
\hline \multirow[t]{2}{*}{16} & A & I & $12.7(n=3)$ & $2.4(n=4)$ & $8.4(n=3)$ \\
\hline & B & I & $13.2(n=2)$ & $2.8(n=1)$ & $7.5(n=3)$ \\
\hline 17 & - & I & $11.6(n=3)$ & $3.3(\mathrm{n}=3)$ & $7.2(\mathrm{n}=3)$ \\
\hline $17 *$ & - & IV & 14.8 (prosoma) & - & - \\
\hline $18 *$ & - & $\mathrm{V}$ & - & - & $5.0(n=1)$ \\
\hline $23^{*}$ & - & I & $9.1(n=4)$ & - & $5.7(\mathrm{n}=3)$ \\
\hline 29 & - & I & - & - & $12.8(\mathrm{n}=1)$ \\
\hline 34 & - & $\mathrm{I} ?$ & - & - & $5.4(n=3)$ \\
\hline \multirow[t]{3}{*}{35} & A & I & $9.2(\mathrm{n}=1)$ & - & $4.8(n=8)$ \\
\hline & B & I & $11.0(n=2)$ & $2.4(\mathrm{n}=1)$ & $7.1(n=2)$ \\
\hline & $\mathrm{C}$ & IV & 10.1 (prosoma) & - & - \\
\hline $36^{*}$ & - & I & $10.4(\mathrm{n}=5)$ & $2.3(\mathrm{n}=3)$ & $4.3(n=4)$ \\
\hline $37 *$ & A & I & $10.8(n=4)$ & $3.4(\mathrm{n}=3)$ & $6.7(\mathrm{n}=3)$ \\
\hline \multirow[t]{2}{*}{37} & A & I & $11.7(n=2)$ & & $6.8(\mathrm{n}=2)$ \\
\hline & 一 & IV & $\sim 11.5$ (prosoma) & - & - \\
\hline
\end{tabular}

Description.-Two trackways (MOR 1084-4, and 1084-23) occur on the same slabs as Kouphichnium isp. traces, whereas MOR 1084-2 and 1084-12 represent slab and counter-slab of a $43 \mathrm{~cm}$ long trackway. This latter trackway progresses across a smooth surface to one marked by fine-scale desiccation cracks; small (maximum diameter $=1.2 \mathrm{~mm}$ ), branched, and horizontally oriented root traces; and $6 \mathrm{~mm}$ wide back-filled burrows (Fig. 10).

These Two Medicine trackways consist of alternating sets of four small tracks arranged in two parallel and separate columns. Tracks within each set are variably arranged.

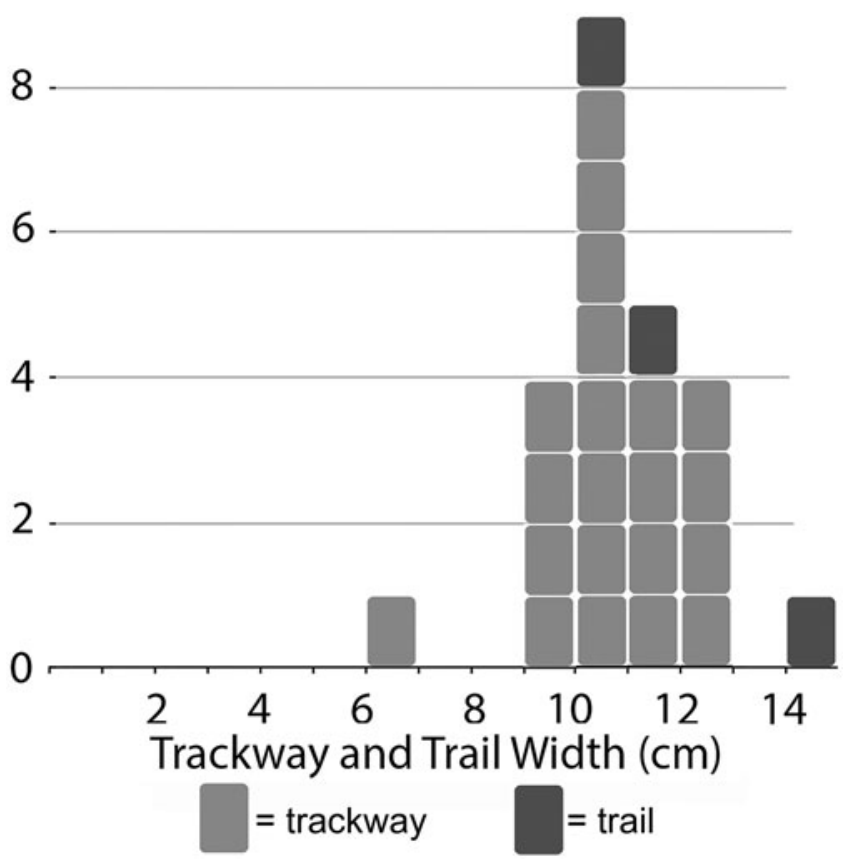

Figure 9. Size distribution of external widths from Kouphichnium isp. trackways and independent prosomal trails from the Two Medicine assemblage. The narrow distribution suggests a mass spawning event.

Commonly, the three anterior tracks form a slight arc, convex forward, to a straight line perpendicular to the direction of motion. The fourth track then sits behind and slightly lateral to the innermost more forward track. The two innermost tracks of the forward three often show a didactyl form, whereas the outer forward track and the trailing track appear more unclear, unidactyl or possibly didactyl (Fig. 10). Two trackways have total widths of $36 \mathrm{~mm}$, a stride length of $21 \mathrm{~mm}$, and individual tracks $4.6-4.9 \mathrm{~mm}$ long. By contrast, the epichnial MOR 1084-23 is larger with a total width of approximately $70 \mathrm{~mm}$, a stride length of $47 \mathrm{~mm}$, and indistinct tracks. None shows any signs of a tail drag.

Materials.-Four slabs preserving three distinct trackways (MOR 1084-2, 1084-4, 1084-12, 1084-23).

Remarks.-Sadler (1993) compared three ichnospecies of Octopodichnus, O. didactylus Gilmore, 1927, O. minor Brady, 1947, and O. raymondi Sadler, 1993 and discussed 


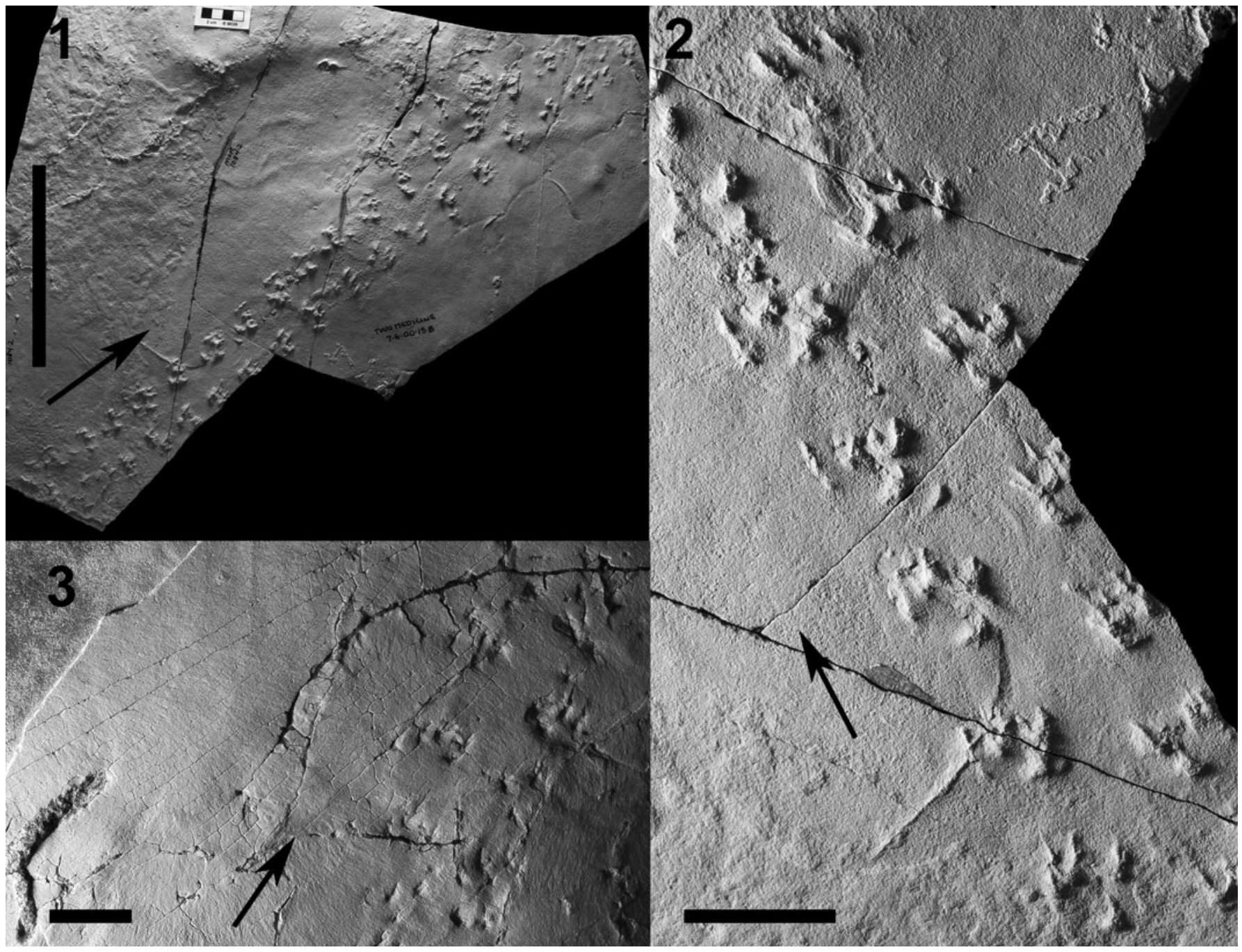

Figure 10. Octopodichnus isp. trackways from the Two Medicine Formation. (1, 2) Hypichnial slab (MOR 1084-2). (3) Epichnial slab (MOR 1084-12) showing trackway crossing from smooth area (lower left) into one marked by fine desiccation cracks, horizontal root traces, and a back-filled burrow. $(\mathbf{1}) \mathrm{Scale}$ bar $=10 \mathrm{~cm}$; $(\mathbf{2}, \mathbf{3})$ scale bars $=2 \mathrm{~cm}$. Black arrows indicate the direction of movement.

their potential trackmakers on the basis of observations of modern spiders and scorpions. According to Sadler (1993), $O$. didactylus and $O$. minor are characterized by bifid tracks and four tracks arranged in fore-aft-arranged arcs that are convex laterally, and $O$. raymondi has circular tracks arranged in a tighter configuration. The Two Medicine specimens are incompatible with these ichnospecies as the individual tracks appear like those of $O$. didactylus and $O$. minor, but their configuration is more akin to, but still different from, that of $O$. raymondi. Consequently, we cannot identify the ichnospecies of Octopodichnus from the Two Medicine Formation. Track form and configuration plus the absence of a tail drag favor an arachnid rather than a scorpion or crustacean as the trackmaker (Sadler, 1993; Martin, 2013), but a definitive trackmaker remains unknown. One trackway (MOR 1084-12) extends across a surface that transitions from smooth to one marked by horizontal root traces and very fine mud cracks (Fig. 10.3), suggesting the trackmaker was walking subaerially in part.

\section{Other traces}

Additional traces include horizontally oriented irregular backfilled burrows ranging in diameter from 3 to $10 \mathrm{~mm}$. Two slabs (e.g., MOR 1084-21) preserve bilaterally symmetric trackways marked by numerous prod marks on each side. These epichnia are relatively small at approximately $12 \mathrm{~mm}$ wide and may represent the ichnotaxon Arthropodichnus. Finally, a large subvertical cylindrical burrow $30 \mathrm{~mm}$ in diameter cuts through MOR 1084-15.

\section{Distribution and paleoenvironment of horseshoe crab traces}

Our survey of the literature on xiphosurid traces yielded 49 occurrences spanning from the Ordovician thru the Paleogene (Table 3 , Fig. 11). We included any locomotion traces (repichnia) whether walking, swimming, or burrowing, as well as resting or sheltering traces (cubichnia). Occurrences are listed by geologic unit (e.g., 
member or formation). We did not attempt to count individual track sites (i.e., outcrop-scale locations). Thus, the tallies represent formation-scale occurrences; trace-rich formations such as the Sohlnhofen Limestone are listed merely as a single occurrence. We did not attempt to resolve any potential issues in ichnotaxonomy but do list the most current taxonomic assessment where possible. Potentially, Table 3 might serve as a starting point for those interested in taxonomic revisions.

Paleozoic traces are uncommon prior to the late Carboniferous, with only a single Ordovician, three Devonian, and one lower Carboniferous (Mississippian) occurrence (Fig. 11). Sites are then much more abundant from the upper Carboniferous (Pennsylvanian) through the Jurassic. Despite the long temporal range of the Cretaceous, it has produced only three described horseshoe crab trace localities to date. The Cenozoic is nearly equally sparse.

Spatially, most traces occur in Laurasia, as only four Gondwana localities have been reported. Through the Carboniferous, occurrences are restricted to low-paleolatitude sites in North America and Europe. By contrast, the six localities in the Permian include one from China and three in Gondwana representing high paleolatitudes. The Triassic has produced no Gondwana traces to date, and sites are confined to North America, Europe, and China. Most Jurassic localities occur in Europe, likely reflecting the shallow tropical marine environments that covered much of the area at the time.

The few Cretaceous localities are widespread, with the two Lower Cretaceous sites coming from Argentina and Japan and the sole Upper Cretaceous locality, described herein, being from Montana. Cenozoic occurrences, as with modern limulid distributions, are limited to Asia and North America.

Through their history, Limulina have been recovered from a variety of depositional environments, both marine and nonmarine. These environments include estuarine, marginal marine, lagoonal, deltaic, lacustrine, floodplain, and fluvial settings. While the earliest traces occur only within marine settings, freshwater localities make up a minor but consistent fraction of the ichnologic record from the lower Carboniferous on (Fig. 11). Although the post-Jurassic record is sparse, several sites appear to represent freshwater environments (Russell, 1940; Matsuoka et al., 2001; Erickson, 2005). Horseshoe crabs would seem to have occupied freshwater environments into the Paleogene in contrast to earlier interpretations (Hauschke and Wilde, 1991; Hasiotis, 2002; Lamsdell, 2016). Nevertheless, the most common environments for preservation of horseshoe crab traces throughout their history are coastal, marginal marine, and shallow marine environments (Table 3). The trace fossil record suggests horseshoe crabs appear to have maintained the ability to colonize either freshwater or saltwater throughout their long geologic span. Although extant taxa are found primarily in marine environments, Carcinoscorpius rotundicauda (Latreille, 1802) remains capable of living in freshwater (Shuster, 1957; Sekiguchi, 1999).

Recently, Lamsdell (2016) surveyed the body fossil record of Xiphosura. He showed (Lamsdell, 2016, fig. 2) that the clade originated in the Ordovician, with diversity remaining low through the early Carboniferous. Diversity then increased dramatically in the late Carboniferous, including a number of freshwater forms. Numbers then decreased through the Triassic and
Jurassic. The ichnological record appears to show a fairly similar pattern, with a sparse and strictly marine early record and then a marked increase in the upper Carboniferous and expansion into freshwater environments. The Paleozoic trace record also suggests some morphologic disparity as evidenced by preserved body outlines in cubichnia, track arrangements and form, and variation in trackway width. Traces then become increasingly dominated by a Kouphicnium lithographicum morphology beginning in the Permian, mimicking the reduction in body fossil diversity (Lamsdell, 2016, fig. 2).

Fischer (1978) described two resting traces, Kouphichnium cordiformis and Corpusculichnus caudatus, from the Ordovician, that respectively suggest a more heart-shaped or crescentic and much more elongate prosoma. The exceptional and very detailed resting trace Protolimulus eriensis Babcock et al., 1995 from the Devonian of Pennsylvania appears to show unusual posterior projections from where normally sit the gills in Limulus. In addition, the opisthosoma bears three prominent spines on each side in contrast to the series of smaller more numerous ones in Limulus. Similarly, Miller (1982) described a more elongate resting trace, Limulicubichnus serratus, and Lucas and Lerner (2005) a very jagged-edged one, both from the upper Carboniferous. By contrast, Eagar et al. (1985) reported on isolated resting traces, Limulicubichnus rossendalensis, with a form closely matching that of modern Limulus.

Caster (1938) described a trackway from the Devonian as Paramphibius, which in contrast to more modern trackways such as Kouphichnium lithigraphicum has the simple tracks arranged more closely to a line perpendicular to the direction of movement and the pusher tracks placed medial to some of the simple tracks. The overlap of the pushers with some simple tracks give the trackway a messier look. These attributes occur together or separately in many Carboniferous specimens. Examples of the former include trackways from the Bude Formation of England (Tyler, 1988) and the Parrsboro Formation of Nova Scotia (Goldring and Seilacher, 1971). Other trackways may have a more chevron-like arrangement of the simple tracks but medially placed pushers (Fillmore et al., 2010; King et al., 2019) or the opposite condition, a perpendicular line of simple tracks and laterally placed pushers (Eagar et al., 1985). Others differ still in having tracks concentrated into two separate columns, as in Kouphichnium aspodon (Buta et al., 2005; Lucas and Lerner, 2005). In addition, some trackways show V- or Y-shaped pusher tracks (Jarzembowski, 1989; Pollard and Hardy, 1991; Lucas and Lerner, 2005). Nevertheless, there are Carboniferous trackways that show a more modern track arrangement and pusher form (Conti et al., 1991).

External widths of both trackways and resting traces show a wide range in the Carboniferous and earlier. Many are less than $4 \mathrm{~cm}$ wide (Caster, 1938; Fischer, 1978; Chisholm, 1983; Tyler, 1988; Fillmore et al., 2010), but others range to over $8 \mathrm{~cm}$ and up to $13 \mathrm{~cm}$ wide (Romano and Melendez, 1985; Conti et al., 1991; King et al., 2019). Small traces are much rarer, particularly in the Mesozoic and Cenozoic (Moreau et al., 2014), seeming to reflect the general loss of small and differently shaped taxa.

In contrast to the varied examples from the Carboniferous, horseshoe crab traces of younger periods generally conform to more Limulus-like body outlines or trackway patterns (e.g., 
Table 3. Horseshoe crab trace fossil occurrences.

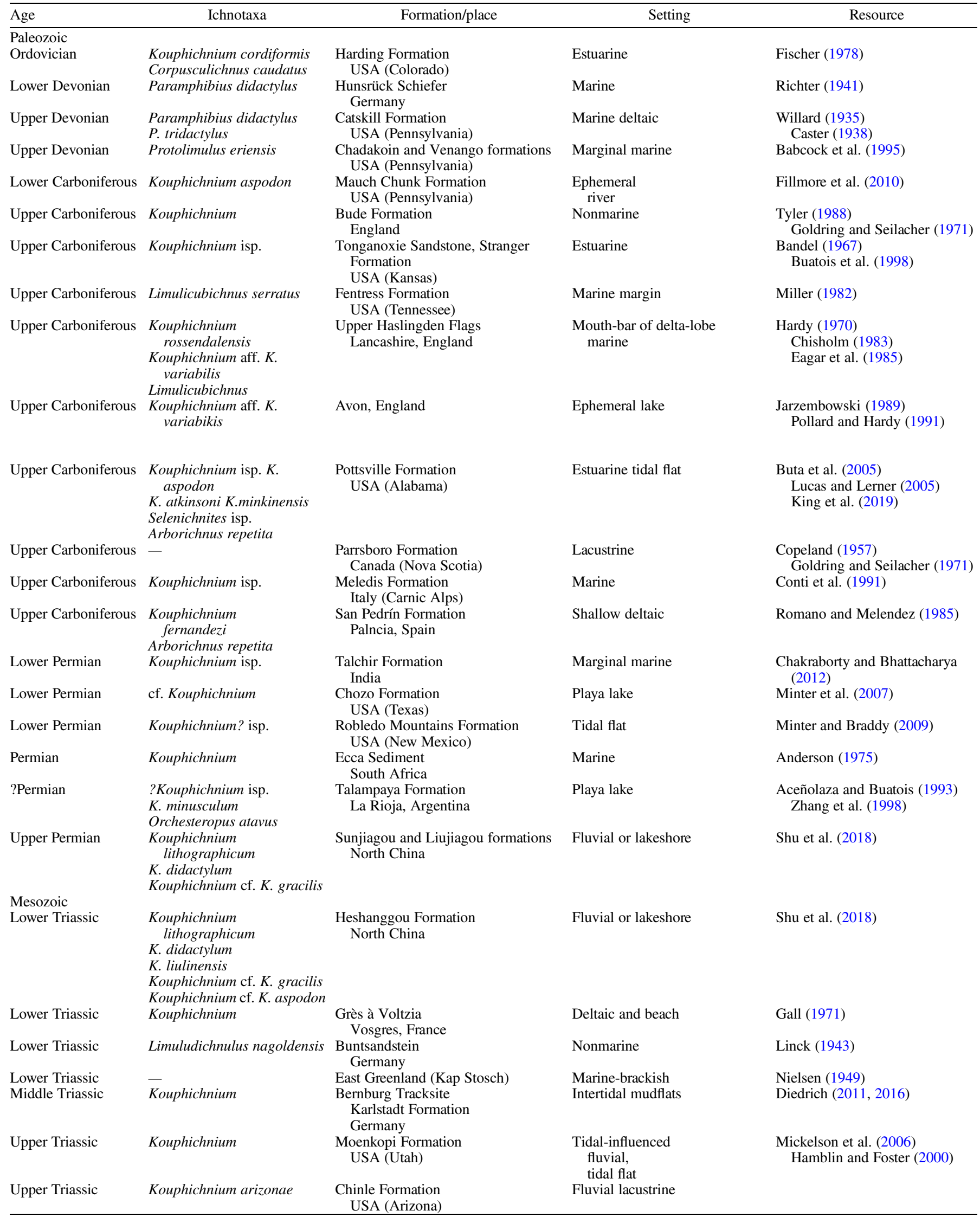


Table 3. Continued.

\begin{tabular}{|c|c|c|c|c|}
\hline Age & Ichnotaxa & Formation/place & Setting & Resource \\
\hline & & & & $\begin{array}{l}\text { Caster (1944) } \\
\text { Hunt et al. (1993) } \\
\text { Hasiotis and Dubiel (1993) }\end{array}$ \\
\hline Upper Triassic & Micrichnus scotti & $\begin{array}{l}\text { Stockton Sandstone } \\
\text { USA (New Jersey) }\end{array}$ & Molasse facies & Goldring and Seilacher (1971) \\
\hline Upper Triassic & $\begin{array}{l}\text { Kouphichnium } \\
\text { lithographicum }\end{array}$ & $\begin{array}{l}\text { Qinglong Formation } \\
\text { Anhui, China }\end{array}$ & Marine & Bi et al. (1995) \\
\hline Upper Triassic & Selenichnites isp. & $\begin{array}{l}\text { Westbury Formation } \\
\text { England }\end{array}$ & Coastal & Wang (1993) \\
\hline Lower Jurassic & cf. Kouphichnium & $\begin{array}{l}\text { Moenave Formation } \\
\text { USA(Utah) }\end{array}$ & Lacustrine & Lucas et al. (2006) \\
\hline Lower Jurassic & - & $\begin{array}{l}\text { Moenave Formation } \\
\text { USA (Wyoming) }\end{array}$ & Tidal flats & Harris and Lacovara (2004) \\
\hline Lower Jurassic & cf. Kouphichnium & $\begin{array}{l}\text { Holy Cross Mountains } \\
\text { Poland }\end{array}$ & Lacustrine & $\begin{array}{l}\text { Pieńkowski and Niedźwiedzki } \\
\text { (2010) }\end{array}$ \\
\hline Middle Jurassic & Selenichnites hundalensis & $\begin{array}{l}\text { Scarborough Formation } \\
\text { England (Yorkshire) }\end{array}$ & Nearshore, lagoonal & $\begin{array}{l}\text { Romano and Whyte } \\
\quad(1987,1990)\end{array}$ \\
\hline Upper Jurassic & Kouphichnium isp. & $\begin{array}{l}\text { Causses Basin } \\
\text { France (Lozère) }\end{array}$ & Lagoon & Moreau et al. (2014) \\
\hline Upper Jurassic & $\begin{array}{l}\text { Kouphichnium } \\
\text { lithographicum }\end{array}$ & $\begin{array}{l}\text { Canjuers Lagerstätte } \\
\text { France (Var) }\end{array}$ & Lagoon & $\begin{array}{l}\text { Peyre De Fabrègues and Allain } \\
\text { (2013) }\end{array}$ \\
\hline Upper Jurassic & $\begin{array}{l}\text { Kouphichnium } \\
\text { lithographicum }\end{array}$ & $\begin{array}{l}\text { Nusplinger Lithographic Limestone } \\
\text { Germany }\end{array}$ & Marine & $\begin{array}{l}\text { Schweigert (1998) } \\
\text { Schweigert and Dietl (2002) }\end{array}$ \\
\hline Upper Jurassic & $\begin{array}{l}\text { Kouphichnium } \\
\text { lithographicum, K. walchi }\end{array}$ & $\begin{array}{l}\text { Solnhofen Lithographic Limestone } \\
\text { Germany }\end{array}$ & Lagoon & $\begin{array}{l}\text { Malz (1964) } \\
\text { Barthel (1974) } \\
\text { Lomax and Racay (2012) }\end{array}$ \\
\hline Upper Jurassic & Kouphichnium isp. & $\begin{array}{l}\text { Morrison Formation } \\
\text { USA (Colorado) }\end{array}$ & Lacustrine, estuarine & Hasiotis (2004) \\
\hline Paleocene & Micrichnus palaeocenus & $\begin{array}{l}\text { Paskapoo Formation } \\
\text { Canada }\end{array}$ & Freshwater & Russell (1940) \\
\hline Paleocene & Kouphichnium pentapodus & $\begin{array}{l}\text { Bullion Creek Formation } \\
\text { USA (North Dakota) }\end{array}$ & Lake & Erickson (2005) \\
\hline Oligocene & Kouphichnium isp. & $\begin{array}{l}\text { Yoshinotani Formation } \\
\text { Japan (Saga) }\end{array}$ & Marine & Oishi et al. (1993) \\
\hline
\end{tabular}

Kouphichnium lithographicum) typical of modern forms, with only a few exceptions in the Permian (Minter and Braddy, 2009) and Triassic (Malz, 1964; Wright and Benton, 1987).

Overall, horseshoe crabs have a rich ichnological record that highlights a number of behaviors. Several works provide excellent images of the diversity to be found among the trackways (e.g., Moreau et al., 2014; Shu et al., 2018; King et al., 2019), with Buta et al. (2005) providing an extensive photographic atlas of the traces from the Carboniferous Pottsville Formation of Alabama.

Some traces of note include the unusual resting trace, Arborichnus repitita (Buta et al., 2005) that appears to represent impressions of the book gills. Selenichnites and Limulicubichnus from the Carboniferous, Triassic, and Jurassic (Romano and Whyte, 1987, 1990) are thought to represent burrowing behavior for feeding (Wang, 1993), with sheltering akin to that found among modern juvenile Limulus (Lucas and Lerner, 2005), and a means to avoid dehydration in shallow intertidal conditions (Eagar et al., 1985). Bandel (1967) interpreted a trackway from the upper Carboniferous of Kansas with two telson drag marks as being produced by a mated pair within an estuarine setting, although Buatois et al. (1997) questioned this interpretation.

Tyler (1988) described an assemblage consisting of many small trackways from the upper Carboniferous Bude Formation of England. Given the exceptionally small widths of these trackways (4 mm to $20 \mathrm{~mm}$ ), Tyler (1988) considered them to represent multiple juvenile instars. Other mass assemblages from the Triassic (Hamblin and Foster, 2000; Diedrich, 2011, 2016), Jurassic (Moreau et al., 2014), and Lower Cretaceous (Fernández and Pazos, 2013) likely represent large reproductive 


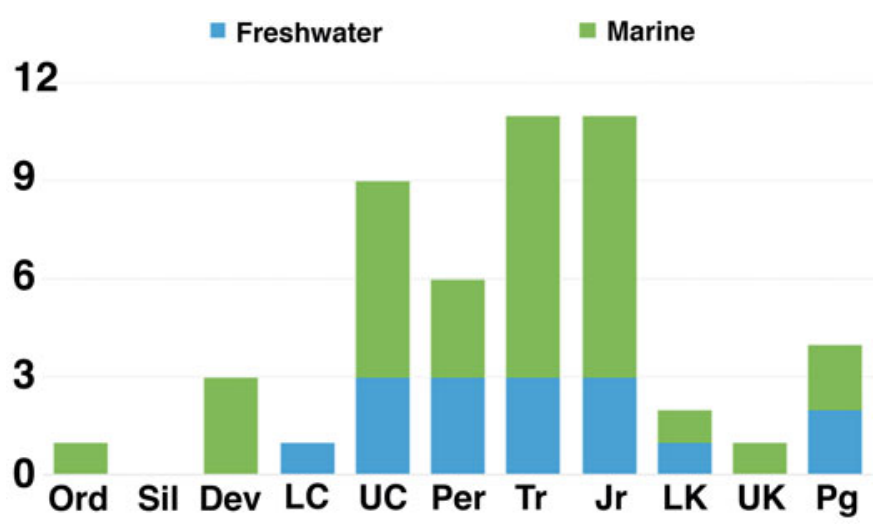

Figure 11. Abundance of horseshoe crab trace occurrences through time. Occurrences are listed in Table 3. Dark and light gray are freshwater and marine localities, respectively. Dev $=$ Devonian; $\mathrm{Jr}=$ Jurassic; LC $=$ lower Carboniferous; LK = Lower Cretaceous; Ord = Ordovician; Per = Permian; Pg = Paleogene; Sil = Silurian; $\quad \mathrm{Tr}=$ Triassic; $\quad \mathrm{UC}=$ upper $\quad$ Carboniferous; $\quad \mathrm{UK}=\mathrm{Upper}$ Cretaceous.

gatherings of horseshoe crabs on tidal flats similar to those observed today. Extensive excavations at the Triassic Bernburg track site have revealed trackways up to $40 \mathrm{~m}$ long as well as evidence of crab predation by various archosaurs (Diedrich, 2011, 2016). The Jurassic site from Lozère, France, is marked by very wide trackways 160-262 $\mathrm{mm}$ across (Moreau et al., 2014). In the Cretaceous Agrio Formation of Argentina, trackways occur crossing three-dimensionally exposed, possibly microbially bound ripples. Although it is interpreted as a mating ground, the average external width of the trackways is only $25 \mathrm{~mm}$.

Mortichnia, or death marches, from the Sohlnhofen Limestone represent probably the most famous horseshoe crab traces. Barthel (1974) noted that few of these specimens exceed an external width of $15 \mathrm{~cm}$ and suggested that they represent juvenile mortality with adults either resistant to or too experienced to perish in these lethal lagoons. One fully excavated mortichnia measures $9.7 \mathrm{~m}$ long and is complete from the point where the crab landed on the seafloor until its ultimate demise (Lomax and Racay, 2012).

Several studies report exceptional large trackways (Oishi et al., 1993; Gaillard, 2011; Moreau et al., 2014) with external widths up to $26 \mathrm{~cm}$ wide, and Moreau et al. (2014) documented changes in body size through an extensive survey of both body and trace fossil dimensions. They found that maximum size increases from the Devonian through the Jurassic; post-Jurassic patterns are more ambiguous due to a sparse fossil record (Moreau et al., 2014). Several papers calculate prosomal widths from trackway external widths (Gaillard, 2011; Peyre de Fabrègues and Allain, 2013; Moreau et al., 2014) based on a sketch by Malz (1964) and a factor of 1.5. On the basis of this factor, Moreau et al. (2014) argued that horseshoe crab body size reached a maximum in the Jurassic. However, these body size calculations are likely significant overestimates. Our observations of Cretaceous prosomal drags associated with pushers suggest a more modest factor of 1.08. Mortichnia may also provide a more direct means to associate body size with external width. Jurassic trackways figured in Goldring and Seilacher (1971) and Lomax and Racay (2012) provide a prosoma-to-externalwidth factor of approximately 1.28. In addition, Moreau et al. (2014) erroneously reported an external width of $24.6 \mathrm{~cm}$ from the Japanese Oligocene as a prosomal body width (Oishi et al., 1993). Both considerations would reduce the overall size and exceptional nature of the Lozère tracks. Maximum external width reported by Oishi et al. (1993) for the Oligocene tracks is $26.5 \mathrm{~cm}$, so on par with the French Jurassic trackways.

Three recent papers address the ichnotaxonomy of Kouphichnium and other horseshoe crab traces: Gaillard (2011), Shu et al. (2018), and King et al. (2019). Gaillard (2011) focused on four behaviors (walking, crawling, dying, and ploughing) and the trackway features that characterize these actions. The emphasis is on the behaviors. Shu et al. (2018) separated trackways by the expression of various parts (telson, pushers, simple tracks, and genial spine), with different combinations being assigned to different species within Kouphichnium, including one new and six established species. Track patterns were not considered. Using this categorization of Shu et al. (2018), one would assign the following species to our Two Medicine types: Types I and II, K. didactylum Willard, 1935; Type III, $K$. aspodon; and Type V, K. fernandezi Romano and Meléndez, 1985 or K. pterodactyli Malz, 1964. Types IV and VI would have no equivalent in the Shu et al. (2018) scheme. King et al. (2019) undertook a review of Kouphichnium using the abundant traces from the Stephen C. Minkin Paleozoic Footprint Site of the Carboniferous Pottsville Formation of Alabama. They recognized several new species but also considered some species within the genus to correspond to non-xiphosurans.

\section{Discussion}

The new Two Medicine locality preserves an abundance of Kouphichnium isp. with a relatively limited size range. Although these traces exhibit varying morphology, here identified as six types, these can be confidently assigned to this ichnogenus on the consistent presence of or association with one or more of the following: bifid simple tracks, more-complex pusher tracks, and telson drag marks. Further, these same attributes, plus the presence of prosomal drag marks, identify the trace maker as a horseshoe crab or limulid.

Precise identification of the Two Medicine Kouphichnium trace maker to a specific genus of horseshoe crab remains difficult. The four species of Cretaceous horseshoe crabs include two forms from North America, Limulus coffini (Reeside and Harris, 1952) from the Campanian Pierre Shale of Colorado and Casterolimulus kletti (Holland et al., 1975) from the Maastrichtian Fox Hills Formation of North Dakota. The opisthosomal width of $L$. coffini (the prosoma is unpreserved) is $8.8 \mathrm{~cm}$, and $C$. kletti measures $10.6 \mathrm{~cm}$ across the genal spines of the prosoma. Using the prosomal-to-opisthosomal width ratios of extant American species L. polyphemus (Sekiguchi, 1999, p. 65, table V-1), the opisthosomal width of $L$. coffini predicts a prosomal width of $13.3 \mathrm{~cm}$ for a male and $12.5 \mathrm{~cm}$ for a female. Smith and Brockman (2014) found that within modern limulids, males range from 10 to $30 \mathrm{~cm}$ and females range from 15 to $30 \mathrm{~cm}$. The range of the Two Medicine trackways and trails is thus consistent in size with the known Cretaceous body fossils (Fig. 9).

Good preservation of the ventral aspects of horseshoe crabs as either body or trace fossils is rare (Fisher, 1982). The Two Medicine Kouphichnium isp. provide clear 
impressions of anterior walking legs and their chelae. These show that the trace maker had bifid chelae on the first walking appendage. Bifid chelae characterize the juveniles of all living limulid species. In three of the four extant species, only females retain these bifid chelae on their first appendages as adults. Adult males modify these chelae into claspers during their final molt. The Indo-Pacific Carcinoscopius rotundicauda is unusual among extant species in that both males and females retain bifid first chelae throughout adulthood. Further, Holland et al. (1975) noted similarities in prosomal morphology between the Cretaceous Casterolimulus kletti and Carcinoscopius rotundicauda and suggested the former might be the ancestor of the latter. Conceivably, C. kletti might have shared similar chelae with $C$. rotunticauda. Among the Two Medicine Kouphichnium isp., trackways clearly show bifid chelae on the first walking leg. The prevalence of this feature may indicate that (1) the trace makers were relatively large juveniles, (2) there was a predominance of female individuals, or (3) it was a trackmaker with $C$. rotunticauda affinities.

The Two Medicine Kouphichnium isp. assemblage consists primarily of a single size, with 20 of 21 measurable traces having widths between 9.1 and $13.2 \mathrm{~cm}$ (Fig. 9). Given the fragmentary nature of the collected slabs, it is possible that some of these traces correspond to a single individual. But the observed range of widths, even within the predominant size class, clearly indicates that the Two Medicine traces represent a multi-individual assemblage. No shallow burrowing trails typical of small (prosomal width $<4 \mathrm{~cm}$ ) Limulus juveniles (Martin, 2013) were observed. Trilobite body fossil assemblages that exhibit similar narrow size-frequency distributions have been interpreted as mating or molting aggregations (Speyer and Brett, 1985; Karim and Westrop, 2002; Paterson et al., 2007). Considering the dramatic and enormous mating events in which extant horseshoe crabs engage (Hanna, 2001), the concentration of Kouphichnium isp. at the Two Medicine locality may reflect a similar mass spawning event and compares to other mating assemblages of the Triassic and Jurassic (Diedrich, 2011, 2016; Moreau et al., 2014). Two Medicine trace dimensions are consistent with known Cretaceous body fossils, although in both cases, there is no certainty that these trace or body fossils represent adults. An alternative interpretation would be that the assemblage represents a gathering of juveniles for some unknown reason (e.g., molting, feeding, environmental disturbance, and so on). The modern Limulus polyphemus exhibits sexual dimorphism, but males and the larger females still overlap in body size (Loveland and Botton, 1992). Since males outnumber females three to one in spawning aggregations (Loveland and Botton, 1992), one would expect a sizefrequency graph of all body sizes from such an aggregation to be positively skewed (i.e., dominated by more numerous, smaller males). Whether this same pattern would be reflected in associated traces remains to be determined. Fernández and Pazos (2013) argued that the male bias in mating assemblages would make dimorphism difficult to recognize in track assemblages.

The Kouphichnium isp. of the Two Medicine occur in thin, coarsening-up silt to sandstone units. These sit within a sequence of laminated to thinly bedded siltstones and sandstones with associated ripples. This sequence overlies more massive mudstones bearing root traces. The entire trace assemblage includes Kouphichnium isp., Cochlichnus isp., Octopodichnus isp., another unidentified arthropod trace, and back-filled burrows. Stratigraphically, the locality sits roughly $90 \mathrm{~m}$ above the top of the Virgelle Sandstone.

The massive mudstones with root traces are consistent with those identified as overbank deposits with paleosol development (Lorenz, 1981; Retallack, 1997). The sequence of platy to laminated fine-grained beds and coarsening-up aspect suggest quiet deposition within standing water. Differences in grain size and deposition from suspension and weak traction currents result in laminations (Dreyer, 1993; Miall, 1996; Spalletti and Pinol, 2005). The laminae together with the fine-grained aspect of these horizons suggest deposition in a relatively low-energy setting. Although laminated sands can occur within foreshore facies, these deposits are generally well sorted (Reinson, 1984). The trace locality is not associated with other shore facies and instead overlies typical floodplain deposits of the Two Medicine Formation.

At outcrops along the Two Medicine River in northern Montana, Rogers (1998) interpreted a discontinuity surface 80 $\mathrm{m}$ above the top of the Virgelle Sandstone as the onset of the Claggett transgression. The $30 \mathrm{~m}$ of overlying fine-grained sediments contain a low-diversity brackish-water molluscan fauna. At outcrops $30 \mathrm{~km}$ south of the Sun River trace locality, Rogers et al. (1993) placed the maximum transgression of the Claggett Seaway at approximately $100 \mathrm{~m}$ above the Virgelle Sandstone. Thus, the stratigraphic position of the Kouphichnium isp. falls within the time frame of the Claggett transgression and very close to its maximum extent. Although full marine conditions as represented by deposition of the Claggett Shale never extend as far west as the Sun River outcrops, presence of flaser bedding and herringbone cross-stratification suggests a tidal influence. Consequently, the stratigraphic position of the Kouphichnium isp. suggests that the presence of horseshoe crabs at this time in the Two Medicine Formation reflects both the Claggett transgression and a marine influence.

Although body fossils are restricted to marine settings after the Early Cretaceous, our review of the Limulina trace fossil distribution through the Mesozoic and Cenozoic failed to eliminate the possibility of Cretaceous freshwater horseshoe crabs. That is, throughout their existence and until relatively recent times, Limulina have inhabited marine and freshwater settings. A freshwater origin for the Two Medicine Kouphichnium isp. cannot currently be eliminated. Discovery of horseshoe crab traces or body fossils higher within the Two Medicine Formation at times of lower sea level could disprove a marine influence for the Sun River traces. But to date, these more heavily studied strata have not produced such a find.

\section{Conclusion}

We describe the first Kouphichnium from the Two Medicine Formation of Montana and only the third record of horseshoe crabs in the Cretaceous of North America. Six variations of Kouphichnium isp. were recognized in this study as reflecting 
differing substrate conditions, undertracks versus true tracks, and epichnial versus hypichnial preservation. Presence of one or more of the following - bifid simple tracks, more-complex pusher tracks, and telson and prosomal drag marks-permit identification of these traces to both the ichnogenus and to horseshoe crabs. The Two Medicine traces include several clear impressions of anterior walking legs and chelae. Estimated body size of these Kouphichnium isp. compares closely to that of the contemporaneous Limulus coffini (Reeside and Harris, 1952) and the slightly younger Casterolimulus kletti (Holland et al., 1975). The limited size range and abundance of Kouphichnium isp. suggests a mating aggregation.

The stratigraphic position of the Two Medicine Kouphichnium isp. correlates with the Claggett or T8 transgression of the Western Interior Seaway (Gill and Cobban, 1973; Rogers, 1998) and suggests the presence of horseshoe crabs in the formation reflects a marine influence. However, sedimentological evidence directly associated with the traces is more ambiguous, suggesting quiet water deposition without a clear indication of fresh, brackish, or marine conditions.

The trace fossil record of Xiphosura runs from the Ordovician through the Paleogene and suggests that horseshoe crabs were capable of occupying freshwater habitats from the lower Carboniferous through at least the Paleogene. Trace abundance is highest from the upper Carboniferous through the Jurassic and likely reflects two factors. First, traces of the upper Carboniferous are diverse as indicated by varying body outlines preserved in resting traces, differing track arrangements and morphology, and body sizes ranging from small to moderate. Trace diversity decreases beginning in the Permian. The second factor is the abundance of suitable sites for trackway preservation in the Late Triassic and Jurassic, especially in Europe. Cretaceous traces are uncommon, and this Two Medicine locality is the first occurrence of horseshoe crab traces in the Late Cretaceous worldwide. Overall, track abundance and diversity would seem to correspond well with the body fossil record (Lamsdell, 2016, fig. 2).

\section{Acknowledgments}

We are grateful to the Earth Science Department of Montana State Lands, the Bureau of Land Management, for allowing the collection of these specimens, and J.H. Horner and J. Scannella at the Museum of the Rockies for curation of these specimens. We thank our Earth Sciences colleagues for helpful discussions and revisions, N. Soji at the Kasaoka City Horseshoe Crab Museum for providing the chance to observe extant horseshoe crabs, and the helpful reviewers. C. Stegner and E. Tackett of MSU provided important recent updates on the specimens and references. Special thanks go to the MSU library staff for processing our numerous requests for journal articles.

\section{References}

Abel, O., 1935, Die Aufklärung einer angeblichen Flugsaurierfährte aus den Sohnhofener Schiefern als die von Limulus walchi: Verhandlungen der Zoologisch-Botanischen Gesellschaft in Wien, v. 84, p. 22-23.

Acen olaza, F.G., and Buatois, L.A., 1993, Nonmarine perigondwanic trace fossils from the late Paleozoic of Argentina: Ichnos, v. 2, p. 183-201.
Anderson, A.M., 1975, Limulid trackways in the Late Paleozoic Ecca Sediments and their paleoenvironmental significance: South African Journal of Science, v. 71, p. 249-251.

Babcock, L.E., Wegweiser, M.D., Wegweiser, A.E, Stanley, T.M., and McKenzie, S.C., 1995, Horseshoe crabs and their trace fossils from the Devonian of Pennsylvania: Pennsylvania Geology, v. 26, p. 2-9.

Babcock, L.E., Merriam, D.F., and West R.R., 2000, Paleolimulus, an early limuline (Xiphosurida), from Pennsylvanian-Permian Lagerstätten of Kansas and taphonomic comparison with modern Limulus: Lethaia, v. 33, p. $129-141$.

Bandel, K., 1967, Isopod and limulid marks and trails in Tongonoxie Sandstone (Upper Pennsylvanian) of Kansas: The University of Kansas Paleontological Contributions, v. 19, p. 1-10.

Barthel, K.W., 1974, Horseshoe crabs aid interpretation of an Upper Jurassic Environment (Solnhofen): Naturwissenschaften, v. 61, p. 428-433.

Bi, D., Guo P., and Qian, M., 1995, Discovery of limulid tracks from Qinglong Formation (Lower Triassic) in Nanling, Anhui: Acta Palaeontologica Sinica, v. 34, p. 714-721.

Błażejowski, B., Niedzwiedzki, G., and Soussi, M., 2017, Limulitella tejraensis, a new species of limulid (Chelicerata, Xiphosura) from the Middle Triassic of southern Tunisia (Saharan Platform): Journal of Paleontology, v. 91, p. $960-967$.

Brady, L.F., 1947, Invertebrate tracks from the Coconino Sandstone of northern Arizona: Journal of Paleontology, v. 21, p. 466-472.

Buatois, L.A., and Mángano, M.G., 2002, Trace fossils from Carboniferous floodplain deposits in western Argentina: implications for ichnofacies models of continental environments: Palaeogeography, Palaeoclimatology, Palaeoecology, v. 183, p. 71-86.

Buatois, L.A., Jalfin, G., and Aceñolaza, F.G., 1997, Permian nonmarine invertebrate trace fossils form southern Patagonia, Argentina: Ichnologic signatures of substrate consolidation and colonization sequences: Journal of Paleontology, v. 71, p. 324-336.

Buatois, L.A., Mangano, M.G., Maples, C.G., and Lanier, W.P., 1998, Ichnology of an Upper Carboniferous fluvio-estuarine paleovalley: the Tonganoxie Sandstone Buildex quarry, eastern Kansas, USA: Journal of Paleontology, v. 72, p. 152-180.

Buta, R.J., Kopaska-Merkel, D.C., Rindsberg, A.K., and Martin, A.J., 2005, Atlas of Union Chapel Mine invertebrate trackways and other traces: Alabama Paleontological Society Monograph No. 1, p. 277-336.

Caster, K.E., 1938, A restudy of the tracks of Paramhphibius: Journal of Paleontology, v. 12, p. 3-60.

Caster, K.E., 1944, Limuloid trails from the Upper Triassic (Chile) of the Petrified Forest National Monument, Arizona: American Journal of Science, v. 242 , p. $74-84$.

Chakraborty, A., and Bhattacharya, H., 2012, Early Permian xiphosurid trackways from India: Geological Society of India, v. 80, p. 129-125.

Chisholm, J.I., 1983, Xiphosurid traces, Kouphichnium aff. variabilis (Linck), from the Namurian Upper Haslingden Flags of Whitworth, Lancashire: Report of Institute of Geological Sciences, v. 83, p. 37-44.

Conti, M.A., Leonardi, G., Manni, R., and Venturini, C., 1991, Limuloid tracks into the Meledis Fm. (Upper Carboniferous, Kasimovian) of the Carnic Alps: Giornale di Geologia, v. 53, p. 151-159.

Copeland, M.J., 1957, The arthropod fauna of the upper Carboniferous rocks of the maritime provinces: Geological Survey of Canada Memoir 286, $110 \mathrm{p}$.

Diedrich, C.G., 2011, Middle Triassic horseshoe crab reproduction areas on intertidal flats of Europe with evidence of predation by archosaurs: Biological Journal of the Linnean Society, v. 103, p. 76-105.

Diedrich, C.G., 2016, Chirotherium trackways and feeding traces on seismic-influenced carbonate intertidals of the Middle Triassic of Central Europe: global food chain reactions onto horseshoe crab reproduction mud flat beaches of the Germanic Basin: Carbonates and Evaporites, v. 31 , p. $187-211$.

Dreyer, T., 1993, Quantified fluvial architecture in ephemeral stream deposits of the Esplugafreda Formation (Palaeocene), Tremp-Graus Basin, northern Spain: Special Publication of the International Association of Sedimentologists, v. 17 , p. 337-362.

Eagar, R.M.C., Baines, J.G., Collinson, J.D., Hardy, P.G., Okolo, S.A., and Pollard, J.E., 1985, Trace fossil assemblages and their occurrence in Silesian (mid-Carboniferous) deltaic sediments of the central Pennine Basin, England: Society of Economic Paleontologists and Mineralogists Special Publication 35, p. 99-149.

Erickson, B.R., 2005, Crocodile and arthropod tracks from the late Paleocene Wannagan Creek Fauna of North Dakota, USA: Ichnos, v. 12, p. 303-308.

Fernández, D.E., and Pazos, P.J., 2013, Xiphosurid trackways in a Lower Cretaceous tidal flat in Patagonia: palaeoecological implications and the involvement of microbial mats in trace fossil preservation: Palaeogeography, Palaeoclimatology, Palaeoecology, v. 375, p. 16-29. 
Fillmore, D.L., Lucas, S.G., and Simpson, E.L., 2010, Invertebrate trace fossils in semi-arid to arid braided-ephemeral-river deposits of the Mississippian middle member of the Mauch Chunk Formation, eastern Pennsylvania, USA: Palaeogeography, Palaeoclimatology, Palaeoecology, v. 292, p. 222-244.

Fischer, W.A., 1978, The habitat of the early vertebrates: trace and body fossil evidence from the Harding Formation (Middle Ordovician), Colorado: Mountain Geologist, v. 15, p. 1-26.

Fisher, D.C., 1982, Phylogenetic and macroevolutionary patterns within the Xiphosurida: Proceedings, Third North American Paleontological Convention, v. 1, p. 175-180.

Gaillard, C., 2011, A giant limulid trackway (Kouphichnium lithographicum) from the lithographic limestones of Cerin (late Kimmeridgian, France): ethological and environmental implications: Swiss Journal of Geosciences, v. 104 , p. $57-72$.

Gall, J.C., 1971, Faunes et paysages du Grès à Voltzia du nord des Vosges. Essai paléoécologique sur le Buntsandstein supérieur: Mémoires du Service de la carte géologique d'Alsace et de Lorraine No. 34, p. 1-318.

Gill, J.R., and Cobban, W.A., 1973, Stratigraphy and geologic history of the Montana Group and equivalent rocks, Montana, Wyoming, and North and South Dakota: United States Geological Survey Professional Paper, v. 776, p. 1-37

Gilmore, C.W., 1927, Fossil footprints from the Grand Canyon: second contribution: Smithsonian Miscellaneous Collections, v. 80, p. 1-101.

Goldring, R., and Seilacher, A., 1971, Limulid undertracks and their sedimentological implications: Neues Jahrbuch für Geologie und Palaontologie, Abhandlungen, v. 137, p. 422-442.

Hamblin, A.H., and Foster, J., 2000, Ancient animal footprints and traces in the Grand Staircase-Escalante National Monument, south-central Utah: Utah Geological Association Publication No. 28, p. 557-568.

Hanna, D.H., 2001, An estimate of population sizes of two horseshoe crab ( Limulus polyphemus) sites in Jamaica Bay, in Tanacredi, J.T., ed., Limulus in the Limelight: New York, Kluwer, p. 147-156.

Häntzschel, W., 1975, Trace fossils and problematica, in Teichert, C., ed, Treatise on Invertebrate Paleontology, Part W, Miscellanea, Supplement 1: Boulder, Colorado, and Lawrence, Kansas, Geological Society of America and University of Kansas Press, p. W1-W269.

Hardy, P.G., 1970, New Xiphosurid trails from the upper Carboniferous of northern England: Palaeontology, v. 13, p. 188-190.

Harris, J.D., and Lacovara, K.J., 2004, Enigmatic fossil footprints from the Sundance Formation (Upper Jurassic) of Bighorn Canyon national recreation area, Wyoming: Ichnos, v. 11, p. 151-166.

Hasiotis, S.T., 2002, Horseshoe crab traces-Kouphichnium; continental trace fossils: SEPM Short Course Notes, v. 51, p. 104-105.

Hasiotis, S.T., 2004, Reconnaissance of Upper Jurassic Morrison Formation ichnofossils, Rocky Mountain Region, USA: paleoenvironmental, stratigraphic and paleoclimatic significance of terrestrial and freshwater ichnocoenoses: Sedimentary Geology, v. 167, p. 177-268.

Hasiotis, S.T., and Dubiel, R.F., 1993, Continental trace fossils of the Upper Triassic Chinle Formation, Petrified Forest National Park, Arizona: New Mexico Museum of Natural History Bulletin no. 3, p. 175-178.

Hauschke, N., and Wilde, V., 1991, Zur Verbreitung und Ökologie mesozoischer Limuliden: Neues Jahrbuch für Geologie und Paläontologie Abhandlungen, v. 183, p. 391-411.

Hitchcock, E., 1858, Ichnology of New England: A Report on the Sandstone of the Connecticut Valley Especially Its Fossil Footmarks, Made to the Gov ernment of the Commonwealth of Massachusetts: Boston, William White, $220 \mathrm{p}$.

Holland, F.D., Erickson, J.M., and O’Brien, D.E., 1975, Casterolimulus; a new Late Cretaceous generic link in limulid lineage: Studies in Paleontology and Stratigraphy, v. 67, p. 235-246.

Hunt, A.P., Lockley, M.G., and Lucas, S.G., 1993, Fossil limuloid trackways from petrified forest National Park, Arizona, USA: New Mexico Museum of Natural History Bulletin No. 3, p. 199-201.

Jarzembowski, A., 1989, Writhlington Geological Nature Reserve: Proceedings of the Geological Association, v. 100, p. 219-234.

Karim, T., and Westrop, S.R., 2002, Taphonomy and paleoecology of Ordovician trilobite clusters, Bromide Formation, south-central Oklahoma: Palaios, v. 17, p. $394-403$.

Kin, A., and Błażejowski, B., 2014, The horseshoe crab of the genus Limulus: living fossil or stabilomorph?: PLoS ONE, v. 9, e108036.

King, O.A., Stimson, M.R., and Lucas, S.G., 2019, The ichnogenus Kouphichnium and related xiphosuran traces from the Steven C. Minkin Paleozoic Footprint Site (Union Chapel Mine), Alabama, USA: ichnotaxonomic and paleoenvironmental implications: Ichnos, v. 26, p. 266-302.

Lamsdell, J.C., 2016, Horseshoe crab phylogeny and independent colonizations of fresh water: ecological invasion as a driver for morphological innovation: Paleontology, v. 59, p. 181-194.
Lamsdell, J.C., Xue, J., and Selden, P.A., 2013, A horseshoe crab (Arthropoda: Chelicerata: Xiphosura) from the Lower Devonian (Lochkovian) of Yunnan, China: Geological Magazine, v. 150, p. 367-370.

Latreille, P.A., 1802, Histoire naturelle, ge'ne'rale et particulie're des crustace's et des insectes: ouvrage faisant suite aux oeuvres de Leclerc de Buffon, et Partie du Cours Complet d'Histoire Naturelle Re'dige' par C.S. Sonnini: Paris, F. Dufart, 478 p.

Linck, O., 1943, Die Buntsandstein-Kleinfährten von Nagold: Neues Jahrbuch für Geologie und Palaontologie, Monatshefte, v. B1, p. 9-27.

Linck, O., 1949, Lebens-Spuren aus dem Schilfsandstein (Mittl. Keuper km 2) NW Wurttembergs und ihre Bedeutung fur die Bildungsgeschichte der Stufe: Jahresheft des Vereins fuer Vaterländische Naturkunde in Württemberg, v. 97-101, p. 1-100.

Linnaeus, C., 1758, Systema naturæ per regna tria naturæ, secundum classes, ordines, genera, species, cum characteribus, differentiis, synonymis, locis. Tomus I. Editio decima, reformata: Stockholm, Salvius, 824 p.

Lomax, D.R., and Racay, C.A., 2012, A long mortichnial trackway of Mesolimulus walchi from the Upper Jurassic Solnhofen lithographic limestone near Wintershof, Germany: Ichnos, v. 19, p. 175-183.

Lorenz, J.C., 1981, Sedimentary and tectonic history of the Two Medicine Formation, Late Cretaceous (Campanian), northwestern Montana [Ph.D. dissertation]: Princeton, Princeton University, 215 p.

Loveland, R.E., and Botton, M.L., 1992, Size dimorphism and the mating system in horseshoe crabs, Limulus polyphemus L.: Animal Behaviour, v. 44, p. 907-916.

Lucas, S.G., and Lerner, A.J., 2005, Lower Pennsylvanian invertebrate ichnofossil from the Union Chapel Mine, Alabama: a preliminary assessment: Alabama Paleontological Society Monograph No. 1, p. 147-151.

Lucas, S.G., Lerner, A.J., Milner, A.R.C., and Lockley, M.G., 2006, Lower Jurassic invertebrate ichnofossils from a clastic lake margin, Johnson Farm, southwestern Utah: New Mexico Museum of Natural History and Sciences, v. 37, p. $128-136$.

Malz, H., 1964, Kouphichnium walchi, die Geschichte einer Fährte und ihres Tieres: Natur und Museum, v. 94, p. 81-97.

Martin, A.J., 2013, Life Traces of the Georgia Coast: Bloomington, Indiana University Press, $670 \mathrm{p}$.

Martinsson, A., 1970, Toponomy of trace fossils: Geological Journal Special Issue 3, p. 323-330.

Matsuoka, H., Hasegawa, Y., Koizumi, A., Nakamura, A., and Yamaguchi, I., 2001, Trail of horseshoe crab, Kouphichnium isp., from the Kuwajima Formation (Tetori Group) in Okuchi Village, Ishikawa Prefecture: Abstracts of the 150th Regular Meeting of the Palaeontological Society of Japan, p. 60.

Miall, A.D., 1996, The Geology of Fluvial Deposits: Sedimentary Facies, Basin Analysis, and Petroleum Geology: New York, Springer, p. 582.

Mickelson, D.L., Huntoon, J.E., and Kvale, E.P., 2006, The diversity and stratigraphic distribution of pre-dinosaurian communities from the Triassic Moenkopi Formation: New Mexico Museum of Natural History Scientific Bulletin, v. 34, p. 132-137.

Miller, M.F., 1982, Limulicubichnus: a new ichnogenus of limulid resting traces: Journal of Paleontology, v. 56, p. 429-433.

Minter, N.J., and Braddy, S.J., 2009, Ichnology of an early Permian intertidal flat: the Robledo Mountains Formation of southern New Mexico, USA: Special Paper in Palaeontology No. 82, p. 1-107.

Minter, N.J., Krainer, K., Lucas, S.G., Braddy, S.J., and Hunt, A.P., 2007, Palaeoecology of an early Permian playa lake trace fossil assemblage from Castle Peak, Texas, USA: Palaeogeography, Palaeoclimatology, Palaeoecology, v. 246, p. 390-423.

Moreau, J.D., Fara, E., Gand, G., Baret, L., and Lafaurie, G., 2014, Gigantism among Late Jurassic limulids: new ichnological evidence from the Causses Basin (Loze're, France) and comments on body-size evolution among horseshoe crabs: Geobios, v. 47, p. 237-253.

Nielsen, E., 1949, On some trails from the Triassic beds of East Greenland: Meddelelser om Grønland, v. 149, p. 1-44.

Nopcsa, F., 1923, Die Familien der Reptilien: Fortschritte der Geologie und Palaeontologie, v. 2, p. 1-210.

Ohtsubo, M., and Ibaraki, M., 1991, Particle-size characterization of flocs and sedimentation volume in electrolyte clay suspensions: Applied Clay Science, v. 6, p. 181-194.

Oishi, H., Matsukuma, A., and Aihara A., 1993, Limulid trace fossils from the Oligocene of Takeo, Saga Prefecture, Japan: Proceedings of Science of Kyushu University (Earth and Planet), v. 18, p. 73-84.

Oppel, A., 1862, Über Fährten im lithographischen Schiefer (Ichnites lithographicus): Paläontologische Mittheilungen aus dem Museum des Königlichen Bayerischen Staates, Stuttgart, v. 1, p. 121-125.

Osgood, R.G., Jr., 1987, Trace fossils, in Boardman, R.S., Cheetham, A.H., and Rowell, A.J., eds., Fossil Invertebrates: Cambridge, Blackwell, p. 663-674. Paterson, J.R., Jago, J.B., Brock, G.A., and Gehling, J.G., 2007, Taphonomy and paleoecology of the emuellid trilobite Balcoracania dailyi (early 
Cambrian, South Australia): Palaeogeography, Palaeoclimatology, Palaeoecology, v. 249, p. 302-321.

Pazos, P., Lazo, D., Tunik, M., Marsicano, C., Fernandez, D., and AguirreUrreta, M., 2012, Paleoenvironmental framework of dinosaur tracksites and other ichnofossils in Early Cretaceous mixed siliciclastic-carbonate deposits in the Neuquén Basin, northern Patagonia (Argentina): Gondwana Research, v. 22, p. 1125-1140.

Peyre de Fabrègues, C., and Allain, R., 2013, A limulid trackway from the Late Jurassic (Tithonian) Lagerstätte of Canjuers (Var, France): Comptes Rendus Palevol, v. 12, p. 181-189.

Pickett, J.W., 1984, A new freshwater limuloid from the Middle Triassic of New South Wales: Palaeontology, v. 27, p. 609-621.

Pieńkowski, G., and Niedźwiedzki, G., 2010, Invertebrate trace fossil assemblages from the lower Hettangian of Sołtyków, Holy Cross Mountains, Poland: Volumina Jurassica, v. 6, p. 109-131.

Pollard, J.E., and Hardy, P.G., 1991, Trace fossils from the Westphalian D of Writhlington Geological Nature Reserve, nr. Radstock, Avon: Proceedings of the Geologists' Association, v. 102, p. 169-177.

Reeside, J.B., and Harris, D.V., 1952, A Cretaceous horseshoe crab from Colorado: Journal of the Washington Academy of Science, v. 42, p. 174177.

Reinson, G.E., 1984, Barrier islands and associated strand-plain systems, in Walker, R.G., ed., Facies Models: Geosciences Canada Reprint Series 1, p. $119-140$

Retallack, G.J., 1997, Dinosaurs and dirt, in Wolberg, D.L., Stump, E., and Rosenberg, G.D., eds., DinoFest International: Philadelphia, Academy of Natural Sciences, p. 345-359.

Richter, R., 1941, Fähren als Zeugnisse des Lebens auf dem Meeres-Grunde: Senckenbergiana, v. 23, p. 216-260.

Riek, E.F., 1968, A re-examination of two arthropod species from the Triassic of Brookvale, New South Wales: Records of the Australian Museum, v. 27, p. 313-321.

Riek, E.F., and Gill, E.D., 1971, A new xiphosuran genus from Lower Cretaceous freshwater sediments at Koonwarra Victoria, Australia: Palaeontology, v. 14 , p. 206-210.

Rogers, R.R., 1997, Two Medicine Formation, in Currie, P.J., and Padian, K., eds., Encyclopedia of Dinosaurs: San Diego, Academic Press, p. 199-204.

Rogers, R.R., 1998, Sequence analysis of the Upper Cretaceous Two Medicine and Judith River Formations, Montana: nonmarine response to the Claggett and Bearpaw marine cycles: Journal of Sedimentary Research, v. 68, p. $615-631$

Rogers, R.R., Swisher, C.C., and Horner, J.R., 1993, ${ }^{40} \mathrm{Ar} /{ }^{39} \mathrm{Ar}$ age and correlation of the non-marine Two Medicine Formation (Upper Cretaceous), northwestern Montana: Canadian Journal of Earth Sciences, v. 30, p. 1066-1075.

Romano, M., and Meléndez, B., 1985, An arthropod (merostome) ichnocoenosis from the Carboniferous of northwest Spain: Congres International de Stratigraphie et de Geologie du Carbonifere Compte Rendu, v. 9, p. 317-325.

Romano, M., and Whyte, M.A., 1987, A limulid trace fossil from the Scarborough Formation (Jurassic) of Yorkshire; its occurrence, taxonomy and interpretation: Proceedings of the Yorkshire Geological Society, v. 46, p. 85-95.

Romano, M., and Whyte, M.A., 1990, Selenichnites, a new name for the ichnogenus Selenichnus: Proceedings of the Yorkshire Geological Society, v. 48, p. 221.

Romano, M., and Whyte, M.A., 2003, The first record of xiphosurid (arthropod) trackways from the Saltwick Formation, Middle Jurassic of the Cleveland Basin, Yorkshire: Palaeontology, v. 46, p. 257-269.

Russell, L.S., 1940, Micrichnus tracks from the Paskapoo Formation of Alberta: Transactions of the Royal Canadian Institute, v. 23, p. 67-74.

Sadler, C.J., 1993, Arthropod trace fossils from the Permian De Chelly Sandstone, Northeastern Arizona: Journal of Paleontology, v. 67, p. 240-249.

Schram, F.R., 1979, Limulines of the Mississippian Bear Gulch limestone of central Montana, USA: Transactions of the San Diego Society of Natural History, v. 19, p. 67-74.
Schweigert, G., 1998, Die Spurenfauna des Nusplinger Plattenkalks (Oberjura, Schwäbische Alb): Stuttgarter Beiträge zur Naturkunde Serie B, v. 262, p. 1-47.

Schweigert, G., and Dietl, G., 2002, Miscellanea aus dem Nusplinger Plattenkalk (Ober-Kimmeridgium, Schwäbische Alb.). 4. Limuliden: Jahresberichte und Mitteilungen des Oberrheinischen Geologischen Vereins NF 84, p. 323-331.

Seilacher, A., 2007, Trace Fossil Analysis: Berlin, Springer-Verlag, p. 226.

Sekiguchi, K., 1999, Biology of Horseshoe Crabs: Japan, Seisaku Douzin, 428 p.

Shu, W., Tong, J., Tian, L., Benton, M.J., Chu, D., Yu, J., and Guo, W., 2018 Limuloid trackways from Permian-Triassic continental successions of North China: Palaeogeography, Palaeoclimatology, Palaeoecology, v. 508, p. $71-90$.

Shuster, C.N., Jr., 1957, Xiphosura (with special reference to Limulus polyphemus): Geological Society of America Memoirs No. 1171-1174.

Shuster, C.N., Jr., 2001a, Two perspectives: horseshoe crabs during 420 million years, worldwide, and the past 150 years in the Delaware Bay area, in Tanacredi, J.T., ed., Limulus in the Limelight: A species 350 Million Years in the Making and in Peril?: New York, Kluwer, p. 17-39.

Shuster, C.N., Jr., 2001b, Tracks and trails, in Tanacredi, J.T., ed., Limulus in the Limelight: A Species 350 Million Years in the Making and in Peril? New York, Kluwer, p. 65-78.

Shuster, C.N., Jr., and Anderson, L.I., 2003, A history of skeletal structure clues to relationships among species, in Shuster, C.N., Jr., Barlow, R.B., and Brockmann, H.J., eds., The American Horseshoe Crab: Cambridge, Harvard University Press, p. 154-188.

Smith, M.D., and Brockmann, H.J., 2014, The evolution and maintenance of sexual size dimorphism in horseshoe crabs: an evaluation of six functional hypotheses: Animal Behaviour, v. 96, p. 127-139.

Spalletti, L.A., and Pinol, F.C., 2005, From alluvial fan to playa: an Upper Jurassic ephemeral fluvial system, Neuquen Basin, Argentina: Gondwana Research, v. 8, p. 363-383.

Speyer, S.E., and Brett, C.E., 1985, Clustered trilobite assemblages in the Middle Devonian Hamilton Group: Lethaia, v. 18, p. 85-103.

St $\varnothing$ rmer, L., 1955, Merostomata, in Moore, R.C., ed., Treatise on Invertebrate Paleontology, Part P, Arthropoda 2: Boulder, Colorado, and Lawrence, Kansas, Geological Society of America and University of Kansas Press, p. 4-41.

Trewin, N.H., 1994, A draft system for the identification and description of arthropod trackways: Palaeontology, v. 37, p. 811-823.

Tyler, D.J., 1988, Evidence and significance of limulid instars from trackways in the Bude Formation (Westphalian), South-west England: Proceedings of the Ussher Society, v. 7, p. 77-80.

Wang, G., 1993, Xiphosurid trace fossils from the Westbury Formation (Rhaetian) of Southwest Britain: Palaeontology, v. 36, p. 111-122.

Willard, B., 1935, Chemung tracks and trails from Pennsylvania: Journal of Paleontology, v. 9, p. 43-56.

Winkler, T.C., 1886, Étude ichnologique sur les empreintes de pas d'animaux fossiles, suivie de la déscription des plaques a impressions d'animaux qui se trouveut au Musée Teyler: Archives du Musée Teyler, v. 2, p. 239-440.

Wright, A.D., and Benton, M.J., 1987, Trace fossils from Rhaetian shoreface deposits of Staffordshire: Palaeontology, v. 30, p. 407-428.

Xing, L.D., Lockley, M.G., He, Q., Matsukawa, M., Persons, W.S., Xiao, Y.-W., and Zhang, J.-P., 2012, Forgotten Paleogene limulid tracks: Xishuangbanania from Yunnan, China: Palaeoworld, v. 21, p. 217-221.

Zhang, G., Buatois, L.A., Mángano, M.G., and Aceñolaza, F.G., 1998, Sedimentary facies and environmental ichnology of a ?Permian playa lake complex in western Argentina: Palaeogeography, Palaeoclimatology, Palaeoecology, v. 138, p. 221-243.

Accepted: 12 March 2020 